\title{
Embryonic and fetal limb myogenic cells are derived from developmentally distinct progenitors and have different requirements for $\beta$-catenin
}

\author{
David A. Hutcheson, Jia Zhao, Allyson Merrell, Malay Haldar, and Gabrielle Kardon ${ }^{1}$ \\ Department of Human Genetics, University of Utah, Salt Lake City, Utah 84112, USA
}

\begin{abstract}
Vertebrate muscle arises sequentially from embryonic, fetal, and adult myoblasts. Although functionally distinct, it is unclear whether these myoblast classes develop from common or different progenitors. Pax 3 and Pax 7 are expressed by somitic myogenic progenitors and are critical myogenic determinants. To test the developmental origin of embryonic and fetal myogenic cells in the limb, we genetically labeled and ablated Pax $3^{+}$and Pax $7^{+}$cells. $\mathrm{Pax}^{+}{ }^{+} \mathrm{Pax} 7^{-}$cells contribute to muscle and endothelium, establish and are required for embryonic myogenesis, and give rise to $\mathbf{P a x} 7^{+}$cells. Subsequently, $\mathbf{P a x} 7^{+}$cells give rise to and are required for fetal myogenesis. Thus, $\mathbf{P a x} 3^{+}$ and $\mathrm{Pax}^{+}$cells contribute differentially to embryonic and fetal limb myogenesis. To investigate whether embryonic and fetal limb myogenic cells have different genetic requirements we conditionally inactivated or activated $\beta$-catenin, an important regulator of myogenesis, in Pax3- or Pax7-derived cells. $\beta$-Catenin is necessary within the somite for dermomyotome and myotome formation and delamination of limb myogenic progenitors. In the limb, $\beta$-catenin is not required for embryonic myoblast specification or myofiber differentiation but is critical for determining fetal progenitor number and myofiber number and type. Together, these studies demonstrate that limb embryonic and fetal myogenic cells develop from distinct, but related progenitors and have different cellautonomous requirements for $\boldsymbol{\beta}$-catenin.
\end{abstract}

[Keywords: Pax3; Pax7; $\beta$-catenin; limb; myogenesis]

Supplemental material is available at http://www.genesdev.org.

Received December 3, 2008; revised version accepted March 3, 2009.

Muscle development, growth, and regeneration take place throughout vertebrate life and are mediated by myogenic progenitors. As with other stem cells, myogenic progenitors are capable of self-renewal and differentiation. Therefore, a key to understanding vertebrate myogenesis is an understanding of the developmental origin of muscle progenitors and the signals that regulate their proliferation and differentiation.

Vertebrate myogenesis occurs in three successive phases, fulfilling different functional needs (for review, see Stockdale 1992; Biressi et al. 2007a). Embryonic myogenesis establishes the basic muscle pattern. Fetal myogenesis is critical for growth and maturation of the muscle. Adult myogenesis allows for postnatal growth and repair of damaged muscle. Each one of these phases involves specification of myoblasts that express the myogenic regulatory factors (MRFs) Myf5, MyoD, and/ or Mrf4; differentiation of committed myocytes; fusion of

${ }^{1}$ Corresponding author.

E-MAIL gkardon@genetics.utah.edu; FAX (801) 581-7796.

Article published online ahead of print. Article and publication date are online at http://www.genesdev.org/cgi/doi/10.1101/gad.1769009. myocytes into multinucleate myofibers; and maturation of myofibers with different speeds of contraction and myosin heavy chain (MHC) isoforms. During embryonic myogenesis (embryonic day 10.5-12.5 [E10.5-E12.5] mouse) (Biressi et al. 2007a) embryonic myoblasts differentiate into primary myofibers. During fetal myogenesis (E14.5-E17.5), fetal myoblasts both fuse to primary fibers and fuse to one another to make secondary myofibers. Finally, during adult myogenesis (postnatal day $0[\mathrm{PO}]$ and onward), muscle growth, fiber maturation, and regeneration are mediated by adult progenitors, satellite cells.

Embryonic, fetal, and adult myoblasts are distinct myogenic populations. These myoblast classes were initially classified based on their in vitro characteristics. They differ in their appearance, media requirements, response to extrinsic signaling molecules, drug sensitivity, and morphology of myofibers they generate (Stockdale 1992; Biressi et al. 2007a). In vivo these myoblasts generate primary, secondary, and adult myofibers that express different MHC isoforms and muscle enzymes (Gunning and Hardeman 1991; Wigmore and Evans 2002). Recent genetic analyses of $P a x 3 / 7$ and $M y f 5 / M y o D / M r f 4$ families of transcription factors and microarray studies reveal that 
the three myoblast classes are specified by different transcription factor combinations and express different genes (Kassar-Duchossoy et al. 2004, 2005; Relaix et al. 2006; Biressi et al. 2007b). Of intense interest is whether embryonic, fetal, and adult myoblasts derive from common or different progenitor populations.

During vertebrate development all axial and limb skeletal muscle originates from progenitors in the somites, epithelial structures that arise from the presomitic mesoderm (psm) (Bryson-Richardson and Currie 2008). Muscle progenitors derive from the dorsal somite, the dermomyotome. Axial muscle forms in two waves from the dermomyotome. Initially, cells delaminate from the dermomyotomal lips to form the underlying primary myotome, and later central dermomyotomal cells translocate to the myotome to form all subsequent axial muscle. Limb muscle originates from progenitors that delaminate from the dermomyotome ventrolateral lip and migrate into the limb (Christ and Brand-Saberi 2002).

Research on muscle progenitors has concentrated on two closely related paired domain homeobox transcription factors, Pax3 and Pax7, expressed in somitic cells (for review, see Relaix et al. 2004; Buckingham 2007). Pax3 is initially expressed (E8) in the psm as somites form, but is progressively restricted, first to the dermomyotome and later to the dorsomedial and ventrolateral dermomyotomal lips. In the limb Pax3 is expressed in somitically derived cells during E10.5-E13.5. Somitic Pax7 expression initiates later (E9) and is restricted to the central region of the dermomyotome. In the mouse limb Pax7 expression begins at E11.5 in somitically derived cells. Pax 7 continues to be expressed during fetal myogenesis and by adult satellite cells. Although Pax3 is not generally expressed in muscle after E13.5, a few adult satellite cells are $\mathrm{Pax}^{+}$(Relaix et al. 2006).

Functionally, Pax3 and $P a x 7$ are important for myogenesis. Pax3 is required for somite segmentation and formation of the dermomyotomal lips (Schubert et al. 2001; Relaix et al. 2004). In addition, Pax3 is required for multiple aspects of limb myogenesis, and all limb muscle is lost in $\mathrm{Pax}^{-1-}$ mice (Relaix et al. 2004, and references therein). Pax3 is sufficient to induce MyoD and Myf5 in vitro (Maroto et al. 1997) and directly binds and transactivates enhancers of Myf5 (Bajard et al. 2006) and $M y o D$ (Hu et al. 2008). $\mathrm{Pax}^{-/-}$mice show no defects in embryonic or fetal myogenesis. However, $\mathrm{Pax} 7$ is required for maintenance of adult satellite cells (Seale et al. 2000; Oustanina et al. 2004; Kuang et al. 2006; Relaix et al. 2006). Pax7 is sufficient to drive myogenic specification in vitro (Seale et al. 2004) and binds a Myf5 enhancer (McKinnell et al. 2008). $\mathrm{Pax}^{-1-} ; \mathrm{Pax}^{-1-}$ mice have no limb muscles (recapitulating the $\mathrm{Pax}^{-/-}$phenotype), but also have no embryonic or fetal axial muscle (although the primary myotome does initially form) (Relaix et al. 2005). Thus, expression of $\mathrm{Pax} 3$ or $\mathrm{Pax} 7$ is critical for assuring the survival of embryonic, fetal, and adult muscle progenitors.

Recent studies have identified $\mathrm{Pax}^{+} / \mathrm{Pax}^{+}$somitic cells as the source of muscle progenitors (Kassar-Duchossoy et al. 2005; Relaix et al. 2005). Using a $P a x 3^{G F P}$ allele (in which GFP is expressed similarly to Pax3 but perdures beyond the transient endogenous Pax3 expression) to track the fate of Pax3 cells and Pax3 and Pax7 expression and loss-of-function experiments, these studies suggest that $\mathrm{Pax}^{+} / \mathrm{Pax} 7^{+}$cells are the common progenitors responsible for all embryonic, fetal, and adult myogenesis in axial and limb muscles. However, both Pax3 and Pax7 are only transiently expressed in progenitors and down-regulated during myogenic differentiation. Therefore, a full assessment of the contribution of $\mathrm{Pax}^{+}$and $\mathrm{Pax} 7^{+}$cells to embryonic, fetal, and adult myoblasts and myofibers requires a lineage analysis in which $\mathrm{Pax}^{+}$and $\mathrm{Pax}^{+}$cells and their progeny are genetically labeled.

Wnt/ $\beta$-catenin signaling is an important regulator of muscle development, and likely to be critical for regulating muscle progenitor proliferation and differentiation. Wnts are secreted ligands for receptor-mediated signaling (Clevers 2006). Cytoplasmic $\beta$-catenin is the central mediator of canonical Wnt signaling. In the absence of Wnts, $\beta$-catenin is phosphorylated and targeted for degradation. Wnt binding to receptors leads to the formation of stabilized, dephosphorylated $\beta$-catenin that translocates to the nucleus where it binds to Tcf/Lef proteins and activates transcription of Wnt-responsive genes.

During axial myogenesis, Wnt/ $\beta$-catenin signaling is important for dermomyotome and myotome formation. Dermomyotome formation requires $\mathrm{Wnt} / \beta$-catenin signaling (Ikeya and Takada 1998; Linker et al. 2003; Schmidt et al. 2004), and Wnts also positively regulate the number of dermomyotomal $\mathrm{Pax} 3^{+}$and $\mathrm{Pax} 7^{+}$progenitors (Galli et al. 2004; Schmidt et al. 2004; Otto et al. 2006). Subsequently, Wnts are necessary and sufficient to promote normal Myf5 and MyoD expression (Munsterberg et al. 1995; Maroto et al. 1997; Tajbakhsh et al. 1998; Borello et al. 1999b; Schmidt et al. 2000; Linker et al. 2003; Galli et al. 2004; Chen et al. 2005; Brunelli et al. 2007). Myf5 is directly regulated by $\beta$-catenin, as two Tcf/Lefbinding sites in the Myf5 enhancer are essential for myotomal expression (Borello et al. 2006). In contrast, $M y o D$ appears to be regulated predominantly via a Wnt/ PKC-mediated pathway (Chen et al. 2005; Brunelli et al. 2007).

In the limb, Wnts and $\beta$-catenin have been found to play several, sometimes conflicting, roles in embryonic myogenesis. Several studies show that Wnts promote embryonic limb myogenesis (Anakwe et al. 2003; GeethaLoganathan et al. 2005, 2006; Takata et al. 2007). However, others found that Tcf/Lef signaling inhibits differentiation of muscle progenitors (Miller et al. 2007). Wnts also regulate embryonic fiber type, via canonical and noncanonical signaling (Anakwe et al. 2003; Takata et al. 2007).

Despite this wealth of studies, several important questions remain unanswered. First, it is unresolved whether Wnt/ $\beta$-catenin signaling is critical cell-autonomously within myogenic cells for skeletal myogenesis in vivo. Second, it is unclear whether $\beta$-catenin's function may differ between different phases of myogenesis. 
In this study we used genetic lineage, ablation, and conditional mutagenesis in the mouse to analyze the developmental origin of limb muscle progenitors and test the role of $\beta$-catenin signaling in regulating the number and differentiation of these progenitors. We genetically labeled and ablated $\mathrm{Pax}^{+}$and $\mathrm{Pax}^{+}$cells in vivo to determine whether $\mathrm{Pax}^{+}$and/or $\mathrm{Pax} 7^{+}$cells are committed myogenic progenitors that give rise to and are required for limb embryonic and fetal muscle. We also tested whether embryonic and fetal limb myogenic cells in vivo have different cell-autonomous requirements for $\beta$-catenin by conditionally inactivating and activating $\beta$-catenin in $\mathrm{Pax}^{+}$and $\mathrm{Pax}^{+}$cells and their progeny. These studies demonstrate that limb embryonic and fetal myogenic cells develop from distinct, but related progenitors and have different cell-autonomous requirements for $\beta$-catenin.

\section{Results}

$\mathrm{Pax}^{+} \mathrm{Pax}^{-}$somitic cells give rise to all $\mathrm{Pax} 7^{+}$and embryonic myogenic cells, while $\mathrm{Pax}^{+}$and $\mathrm{Pax}^{+}$cells contribute to fetal myogenic cells in the limb

To test whether $\mathrm{Pax}^{+}$and $\mathrm{Pax}^{+}$somitic cells are the progenitors for embryonic and fetal myogenic cells in the limb, we conducted a lineage analysis of $\mathrm{Pax}^{+}$and $\mathrm{Pax} 7^{+}$ cells. We genetically labeled $\mathrm{Pax} 3^{+}$or $\mathrm{Pax} 7^{+}$cells and their progeny using Pax $3^{\text {Cre }}$ (Engleka et al. 2005) or Pax $7^{\text {iCre }}$ (Keller et al. 2004) mice, in which Cre is faithfully expressed in all cells in which either $\mathrm{Pax} 3$ or $\mathrm{Pax} 7$ is normally expressed. These mice were crossed with $R 26 R^{\text {LacZ }}$ reporter mice (Soriano 1999), in which LacZ is expressed in response to Cre recombinase. In $\mathrm{Pax} 3^{\mathrm{Cre} /+}$; $R 26 R^{\mathrm{LaCZ} /+}$ or $\mathrm{Pax} 7^{\mathrm{iCre} /+}, \mathrm{R}_{2} 6 \mathrm{R}^{\mathrm{LaCZ} /+}$ mice $\mathrm{Pax} 3^{+}$or $\mathrm{Pax} 7^{+}$ cells and their progeny are positive for $\beta$-galactosidase ( $\beta$-gal) activity.

To confirm that $\mathrm{Pax}^{+}$and $\mathrm{Pax} 7^{+}$cells give rise to $\operatorname{limb}$ muscle and test the temporal-spatial relationship between the Pax3 and Pax7 lineages, we analyzed Pax $3^{\mathrm{Cre} /+}$; R26R ${ }^{\mathrm{LacZ} /+}$ and $\mathrm{Pax} \mathrm{iCre/+}^{\mathrm{iC}}$ R26 $\mathrm{R}^{\mathrm{LaCZ} /+}$ E9-E14.5 embryos. Whole-mount analysis of $\mathrm{Pax}^{\mathrm{Cre} /+} ; \mathrm{R}_{2} 6 \mathrm{R}^{\mathrm{LacZ} /+}$ embryos shows $\beta$-gal ${ }^{+}$cells are present in somites by E9 (beginning in the newly most formed somite, somite stage I) and in limbs by E10.5 with strong expression in all limb muscles by E14.5 (Suppplmental Fig. 1A-C; data not shown). In $\mathrm{Pax}^{\mathrm{iCre} /+}{ }_{;} \mathrm{R} 26 \mathrm{R}^{\mathrm{LacZ/+}}$ embryos, a few $\beta-\mathrm{gal}^{+}$cells are present in somites at E9.5 (beginning at somite stage $\mathrm{X}$ ), with increasing numbers at E10.5, while $\beta$-gal ${ }^{+}$cells are absent in the limbs at E10.5, just beginning at E11.5, and widely expressed in all limb muscles by E14.5 (Supplemental Fig. 1E-G; data not shown). Thus, both $\mathrm{Pax}^{+}$and $\mathrm{Pax}^{+}$cells contribute to all limb muscles by E14.5. However, Pax7-derived cells appear later in somites and limbs relative to Pax3-derived cells, consistent with previous Pax3 and Pax7 RNA expression studies (e.g., Relaix et al. 2004). To test whether Pax $7^{+}$cells may be derived from and a subset of Pax3-derived cells, we analyzed sections of E10.5-E14.5 $\mathrm{Pax}^{\mathrm{Cre} /{ }^{+}}{ }_{\text {R }} 26 \mathrm{R}^{\mathrm{LaCZ} /+}$ embryos. In the $\operatorname{limb}$ all $\mathrm{Pax} 7^{+}$cells are $\beta$-gal ${ }^{+}$and thus derived from
Pax $^{+}$cells (Fig. 1A-D; data not shown). Therefore, in the limb both $\operatorname{Pax}^{+}$and $\operatorname{Pax} 7^{+}$somitic cells contribute to all muscles by E14.5, and $\mathrm{Pax} 7^{+}$cells are derived from and a subset of the Pax3 lineage.

The temporal differences in $\mathrm{Pax} 3$ and $\mathrm{Pax} 7$ gene expression and lineage suggest that $\mathrm{Pax} 3^{+}$and $\mathrm{Pax} 7^{+}$cells could be differentially contributing to limb embryonic myogenic cells. Myoblasts and myofibers present in the limb between E10.5 and E12.5 have been classified as embryonic myogenic cells based on their distinctive in vitro characteristics (molecular markers distinguishing embryonic vs. fetal myogenic cells are only just starting to be identified) (Biressi et al. 2007a,b). Therefore, we examined hindlimb sections


embryos. In $\mathrm{Pax}^{\mathrm{Cre} /+} ; R 26 \mathrm{R}^{\mathrm{LacZ} /+}$ limbs all MyoD ${ }^{+}$myoblasts (Fig. 1E-H) and myosin ${ }^{+}$myofibers (Fig. 2A) are $\beta$-gal ${ }^{+}$ and thus derived from $\mathrm{Pax}^{+}$cells. In contrast, in E12.5 Pax ${ }^{\text {iCre/+}}{ }_{;} R 26 R^{\text {LacZ/+ }}$ embryos, only a few MyoD ${ }^{+}$myoblasts (Fig. 1I-L) and myosin ${ }^{+}$myofibers (Fig. 2D) are $\beta$-gal ${ }^{+}$. This demonstrates that $\mathrm{Pax}^{+}$cells give rise to all embryonic myoblasts and myofibers, while $\mathrm{Pax} 7^{+}$cells give rise to few embryonic myogenic cells. This indicates that in the limb almost all embryonic myoblasts and myofibers have arisen directly from $\mathrm{Pax}^{+}$cells without ever having expressed Pax7.

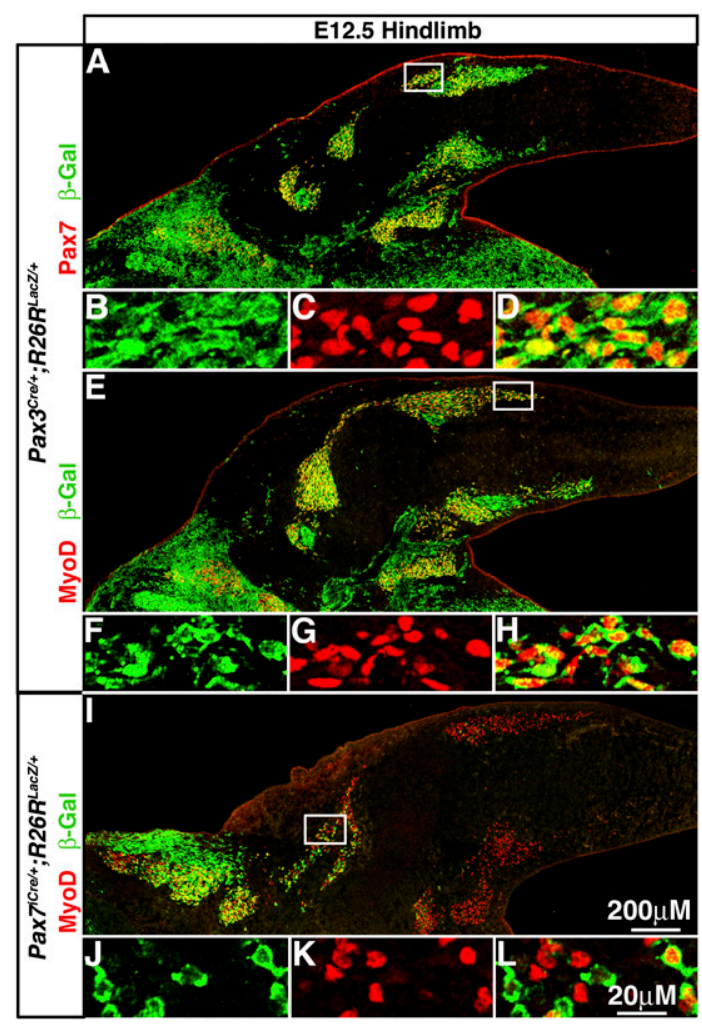

Figure 1. $\mathrm{Pax}^{+}$somitic cells give rise to all $\mathrm{Pax} 7^{+}$cells and embryonic myoblasts, while Pax $7^{+}$cells give rise to only a few myoblasts at E12.5 in the limb. $(A-H)$ All $\mathrm{Pax}^{+}$cells and $\mathrm{MyoD}^{+}$ embryonic myoblasts are $\beta$-gal ${ }^{+}$in $\mathrm{E} 12.5 \mathrm{Pax}^{\mathrm{Cre} /+}{ }_{;}$R2 $6 R^{\mathrm{LacZ} /+}$ hindlimbs. $(I-L)$ Only a few proximal $\mathrm{MyoD}^{+}$myoblasts are $\beta$-gal ${ }^{+}$in E12.5 $\mathrm{Pax}^{\mathrm{iCre} /+}{ } R_{2} 26 \mathrm{R}^{\mathrm{LacZ} /+}$ hindlimbs. 


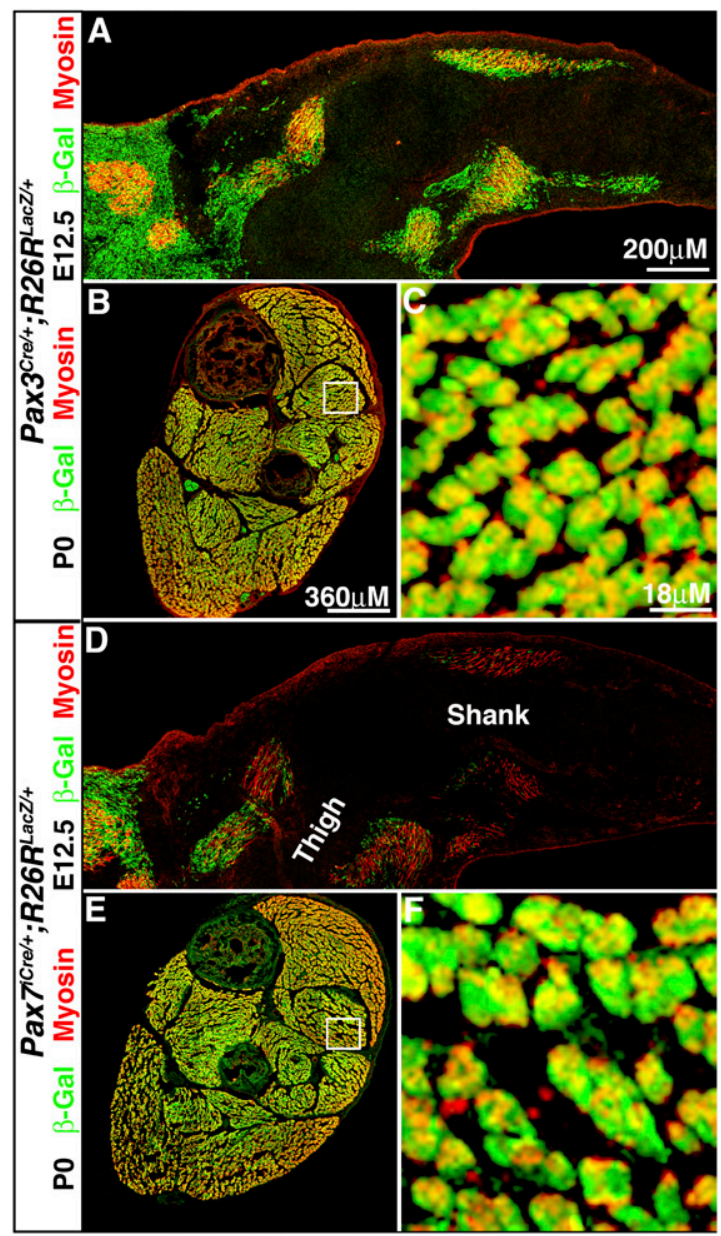

Figure 2. In the limb embryonic myofibers are derived from $\mathrm{Pax}^{+} \mathrm{Pax} 7^{-}$somitic cells, while fetal myofibers have contributions from $\mathrm{Pax} 3^{+}$and $\mathrm{Pax} 7^{+}$somitic cells. At E12.5 all embryonic myosin ${ }^{+}$myofibers are $\beta$-gal ${ }^{+}$in $\mathrm{Pax}^{\mathrm{Cre} /+} ; \mathrm{R}^{2} 6 \mathrm{R}^{\mathrm{LacZ} /+}$ hindlimbs $(A)$, while only a few proximal myosin ${ }^{+}$myofibers are $\beta$-gal ${ }^{+}$in Pax ${ }^{\text {iCre/+}} ; R 26 R^{\text {LacZ/+ }}$ hindlimbs $(D)$. At P0 all fetal myosin ${ }^{+}$ myofibers are $\beta$-gal ${ }^{+}$in $\mathrm{Pax}_{3}{ }^{\mathrm{Cre} /+}{ }_{;} R_{2} 6 R^{\mathrm{LaCZ} /+}(B, C)$ and $\mathrm{Pax} 7^{\mathrm{iCre} /+}$; $R 26 R^{\text {LacZ/+ }}(E, F)$ hindlimbs.

The whole-mount analysis of E14.5 $\mathrm{Pax}^{\mathrm{Cre} /+}$; R26R $\mathrm{RacZ} /+^{\mathrm{La}}$ and $\mathrm{Pax} 7^{\mathrm{iCre} /+}$; $R 26 \mathrm{R}^{\mathrm{LacZ} /+}$ limbs suggests that both $\mathrm{Pax}^{+}$and $\mathrm{Pax}^{+}$cells may contribute to fetal myogenic cells. Myogenic cells present in the limb between E14.5 and E17.5 have been classified as fetal myogenic cells (Biressi et al. 2007a,b). We examined hindlimbs sections from newly born (P0) $\mathrm{Pax}^{\mathrm{Cre} /+}$; R26R $\mathrm{LacZ} /+$ and $\mathrm{Pax} 7^{\mathrm{iCre} /+} ; \mathrm{R}_{26} \mathrm{R}^{\mathrm{LacZ} /+}$ mice, just at the end of fetal myogenesis. In both $\mathrm{Pax}^{\mathrm{Cre} /{ }^{+}} ; R_{2} 6 \mathrm{R}^{\mathrm{LacZ} /+}$ and $\mathrm{Pax}^{\mathrm{iCre} /+} ; R 26 \mathrm{R}^{\mathrm{LacZ} /+}$ limbs, all myosin ${ }^{+}$myofibers are $\beta$-gal ${ }^{+}$(Fig. 2B,C,E,F). This demonstrates that fetal myofibers have contributions from both $\mathrm{Pax}^{+}$and $\mathrm{Pax} 7^{+}$cells.

In summary, our lineage analysis shows that $\mathrm{Pax}^{+}$ and $\mathrm{Pax}^{+}$cells contribute differentially to embryonic and fetal myogenic cells in the limb. Pax $3^{+} \operatorname{Pax} 7^{-}$cells give rise to all embryonic myoblasts and myofibers and also $\mathrm{Pax} 7^{+}$cells. Subsequently, all fetal myofibers have contributions from both $\mathrm{Pax}^{+}$and $\mathrm{Pax} 7^{+}$cells.
$\mathrm{Pax}^{+}$, but not Pax $7^{+}$somitic cells are required for embryonic limb myogenesis

The finding that all embryonic myogenic cells in the limb are derived from $\mathrm{Pax}^{+}$cells, while only a few are derived from $\operatorname{Pax} 7^{+}$cells, suggests that the Pax3 lineage is required for embryonic myogenesis, while the Pax7 lineage is not. To test whether $\mathrm{Pax} 3^{+}$and/or Pax $7^{+}$cells and their progeny are required for embryonic limb myogenesis, we genetically ablated $\mathrm{Pax}^{+}$and $\mathrm{Pax}^{+}$cells. In $\mathrm{Pax} 3^{\mathrm{Cre} /+}$; $R 26 R^{D T A /+}$ and $\mathrm{Pax}^{\mathrm{iCre} /+} ; R_{2} 6 R^{D T A /+}$ mice, Cre activates the expression of diphtheria toxin (DTA) and kills $\mathrm{Pax}^{+}$and $\mathrm{Pax}^{+}$cells (Wu et al. 2006). $\mathrm{Pax}^{\mathrm{Cre} /+}$; $R 26 R^{D T A /+}$ embryos do not survive beyond E12.5. In these embryos, myosin ${ }^{+}$myofibers are present in the head (data not shown), consistent with the lack of Pax3 expression in myogenic progenitors in head muscles (Horst et al. 2006). However, there is no Pax7, MyoD, or myosin expression in the limb or trunk (Fig. 3A-C; data not shown), indicating a complete lack of appendicular and axial myogenesis. $\operatorname{Pax} 7^{i \mathrm{Cre} /{ }_{+}} ; R_{2} 6 R^{D T A /+}$ mice survive until birth. In contrast to $\mathrm{Pax} 3^{\mathrm{Cre} /+} ; \mathrm{R}_{2} 6 \mathrm{R}^{\mathrm{DTA} /+}$, there is a normal embryonic pattern of $\mathrm{MyoD}^{+}$myoblasts and myosin ${ }^{+}$myofibers in E14.5 $\mathrm{Pax}^{\mathrm{iCre} /+}{ }^{+} \mathrm{R}_{26 R^{D T A /+}}$ hindlimbs, just at the end of embryonic myogenesis (Fig. 3D,E).

To rule out that the normal muscle pattern in $\mathrm{Pax} 7^{\mathrm{iCre} /+}$; $R 26 R^{D T A /+}$ mice is due to the presence of surviving $\operatorname{Pax} 7^{+}$progenitors, we investigated the efficiency of ablation of $\mathrm{Pax}^{+}$cells. Previous studies (Wu et al. 2006; Haldar et al. 2008) demonstrated that the DTA in the $R 26 R^{D T A /+}$ mice specifically kills all $\mathrm{Cre}^{+}$cells within $24 \mathrm{~h}$ of Cre expression. In addition, Cre appears to be expressed in nearly all $\mathrm{Pax}^{+}$cells since in $\mathrm{Pax}{ }^{\mathrm{iCre} /+}$; $R 26 R^{\mathrm{LacZ} /+}$ nearly all $\mathrm{Pax} 7^{+}$cells are $\beta$-gal ${ }^{+}$(Supplemental Fig. $2 \mathrm{~A}, \mathrm{~B})$; the few cells that are $\mathrm{Pax} 7^{+} \beta$-gal ${ }^{-}$are likely ones in which the reporter is not yet expressed. Likewise, in $\mathrm{Pax}^{\mathrm{iCre} /+} ; R 26 \mathrm{R}^{\mathrm{DTA} /+}$ there is almost a complete loss of $\operatorname{Pax} 7^{+}$cells (Supplemental Fig. 2C,D); the few $\operatorname{Pax} 7^{+}$are likely cells that have not yet been killed by the DTA. Thus, in the $\operatorname{Pax} 7^{i C r e /+} ; R 26 R^{D T A /+}$ mice, it is probable that all $\operatorname{Pax} 7^{+}$cells are being killed and the remaining embryonic myoblasts and myofibers are derived from $\operatorname{Pax} 3^{+} \operatorname{Pax} 7^{-}$ progenitors.

These data demonstrate that the Pax3 lineage, but not the Pax7 lineage, is required to give rise to limb (and axial) embryonic myogenic cells. Therefore, during normal development $\operatorname{Pax} 3^{+} \mathrm{Pax} 7^{-}$somitic progenitors are essential for embryonic myogenesis. The $\mathrm{Pax} 3^{+} \mathrm{Pax} 7^{-}$progenitors are also required to give rise to $\mathrm{Pax} 7^{+}$muscle progenitors.

\section{Limb fetal myogenesis is compromised in the absence of $\mathrm{Pax}^{+}$somitic cells}

Our lineage analysis demonstrated that all fetal myofibers are derived from Pax3 and Pax7 progenitors, suggesting these progenitors are essential for fetal myogenesis. We tested whether Pax $7^{+}$progenitors are required for fetal myogenesis by examining P0 Pax $7^{i C r e /+}{ }_{;} R 26 R^{D T A /+}$ mice, at the end of fetal myogenesis and just prior to their death 


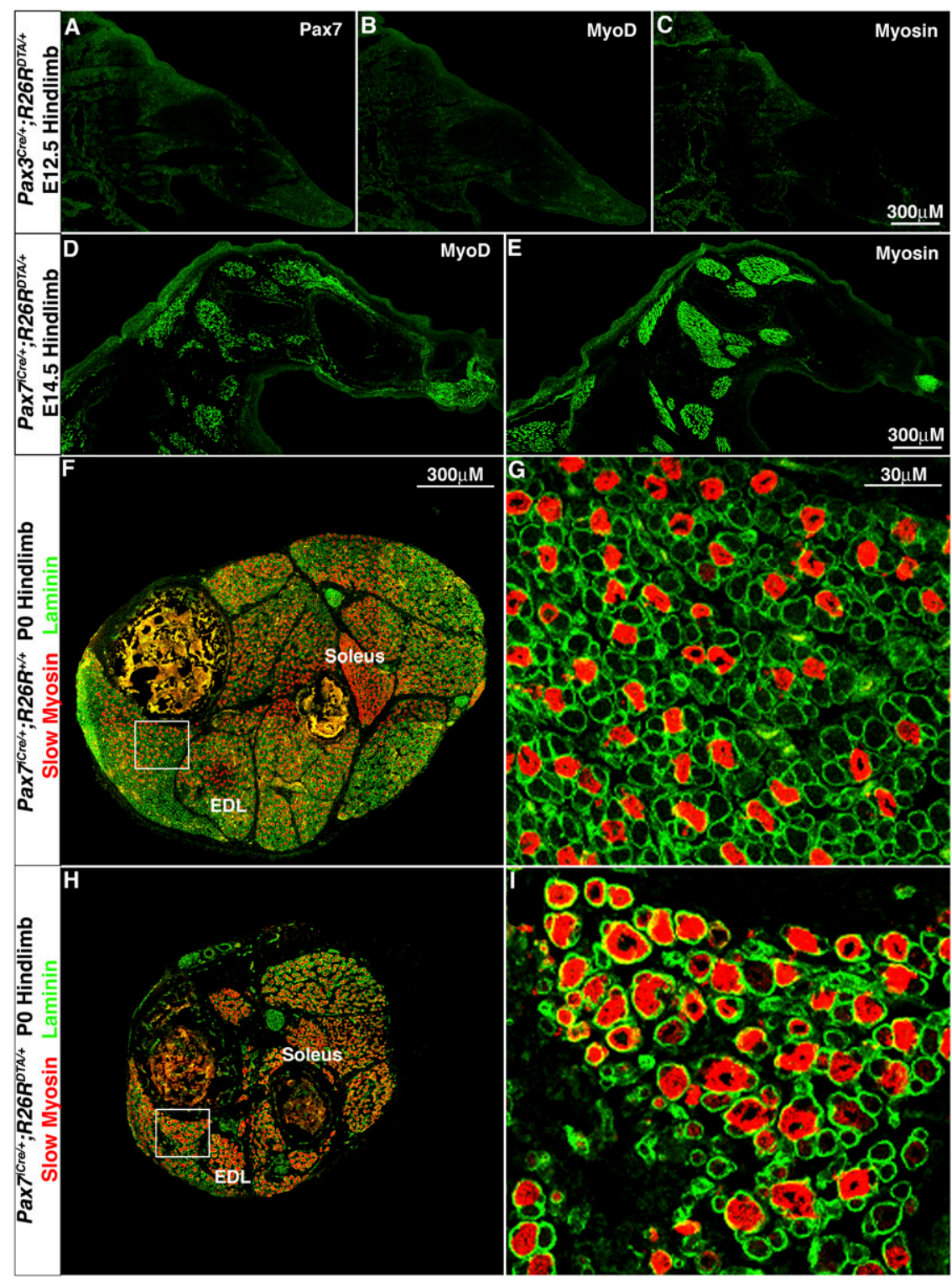

Figure 3. In the limb $\mathrm{Pax}^{+}$somitic cells, but not $\mathrm{Pax} 7^{+}$somitic cells are required for embryonic myogenesis, while Pax $7^{+}$cells are required for fetal myogenesis. $(A-C)$ E12.5 $\mathrm{Pax}^{\mathrm{Cre} /{ }^{\mathrm{C}}} ; \mathrm{R}_{2} 6 \mathrm{R}^{\mathrm{DTA} /+}$ hindlimb sections show a complete loss of $\mathrm{Pax} 7^{+}$progenitors $(A), \mathrm{MyoD}^{+}$myoblasts $(B)$, and myosin $^{+}$myofibers $(C)$, indicating a complete loss of embryonic limb myogenesis when $\mathrm{Pax}^{+}$cells are ablated. $(D, E)$ E14.5 Pax ${ }^{i C r e /+} ; R 26 R^{D T A /+}$ hindlimb sections show a normal pattern of embryonic MyoD ${ }^{+}$myoblasts $(D)$ and myosin ${ }^{+}$myofibers $(E)$ when $\operatorname{Pax} 7^{+}$cells are ablated. P0 Pax ${ }^{\text {iCre/+ }} ; R 26 R^{D T A /+}$ shank cross-section shows a basic muscle pattern $(H, I)$, but muscles contain fewer laminin ${ }^{+}$myofibers with a higher proportion of slow myosin ${ }^{+}$ myofibers compared with control $\mathrm{Pax} \mathrm{7}^{\mathrm{iCre} /{ }^{+}}$; $R 26 R^{+/+}$sections $(F, G)$. (examination of the requirement for $\mathrm{Pax} 3^{+}$progenitors was precluded by the E12.5 death of $\mathrm{Pax} 3^{\mathrm{Cre} /+} ; R_{2} 6 R^{D T A /+}$ mice). The basic pattern of muscles is present in P0 $\mathrm{Pax}^{\mathrm{iCre/+}} ; \mathrm{R}^{2} 6 \mathrm{R}^{\mathrm{DTA} /+}$ mice, but each muscle is much smaller and contains fewer myofibers (Fig. $3 \mathrm{H}$ vs. F; Supplemental Fig. 3). Also, a higher proportion of myofibers express slow MHC in most muscles (with the exception of the normally slow-enriched soleus) in the

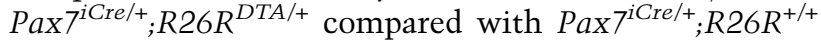
(Fig. 3F-H ; Supplemental Fig. 3). The proportion of slow myofibers in PO limbs is determined by maturation of both embryonic and fetal muscle. Previous studies showed that all embryonic myofibers express slow myosin and then fibers destined to become fast gradually lose slow myosin (Condon et al. 1990; Gunning and Hardeman 1991). In contrast, most fetal myofibers never express slow (Kelly and Rubinstein 1980; Condon et al. 1990; Gunning and Hardeman 1991; Biressi et al. 2007a).
Therefore, the increased proportion of slow myofibers in Pax ${ }^{\text {iCre/+}}{ }_{;} R 26 R^{D T A /+}$ mice likely results from a retention of slow-expressing embryonic myofibers and a decreased formation of fetal myofibers, which mainly do not express slow myosin. Taken together, the overall decreased number of myofibers and the increased proportion of slow myofibers in the $\mathrm{Pax}^{\mathrm{iCre/+}}{ }_{;} \mathrm{R}_{26 \mathrm{R}^{\mathrm{DTA} /+} \text { mice suggest that }}$ fetal myofibers have not differentiated and that $\operatorname{Pax} 7^{+}$ progenitors are required for their differentiation.

Pax3 $^{+}$, but not Pax $7^{+}$, somitic cells give rise to $\operatorname{limb}$ endothelial cells

Our whole-mount analysis of $\mathrm{Pax}^{\mathrm{Cre} /+}{ } \mathrm{R}_{2} 6 \mathrm{R}^{\mathrm{LaCZ} /+}$ limbs revealed obvious nonmyogenic $\beta$-gal ${ }^{+}$cells that appeared to be associated with vessels in the shank and foot (Supplemental Fig. 1C,D). Previous studies have shown that somitic cells contribute to the endothelial cells of 
the limb vasculature (Pardanaud et al. 1996; He et al. 2003; Huang et al. 2003). Therefore, $\mathrm{Pax}^{+}$and/or Pax $7^{+}$ somitic cells could give rise to limb endothelial cells. To test whether $\operatorname{Pax}^{+}$cells contribute to endothelial cells, we immunolabeled E14.5 sections of $\mathrm{Pax}_{3}{ }^{\mathrm{Cre} /+}{ }_{;} \mathrm{R}_{2} 6 \mathrm{R}^{\mathrm{LaCZ} /+}$ limbs with an endothelial marker, CD31. We found $\beta$-gal ${ }^{+} \mathrm{CD} 31^{+}$cells, indicating that $\mathrm{Pax}^{+}$cells give rise to endothelial cells (Fig. 4A-D). Most Pax3-derived CD31 ${ }^{+}$ cells were found in superficial vessels directly below the epidermis and a few in deeper vessels. Overall, only a small proportion of limb endothelial cells were $\beta$-gal ${ }^{+}$ and therefore derived from $\mathrm{Pax}^{+}$somitic cells. The majority of limb endothelial cells appear to be derived from nonsomitic sources (Pardanaud et al. 1996). Nevertheless, the finding of Pax3-derived endothelial cells demonstrates that $\mathrm{Pax}^{+}$somitic cells are not committed to a myogenic fate in the limb, but are able to differentiate into either myogenic or endothelial cells. In contrast to Pax3, neither whole-mount nor section analysis of Pax ${ }^{\text {iCre/+}} ; R_{2} 6 R^{\text {LacZ/+ }}$ limbs (Fig. 4E-H; Supplemental Fig. $1 \mathrm{G}, \mathrm{H})$ revealed $\beta$-gal ${ }^{+}$endothelial cells and indicates

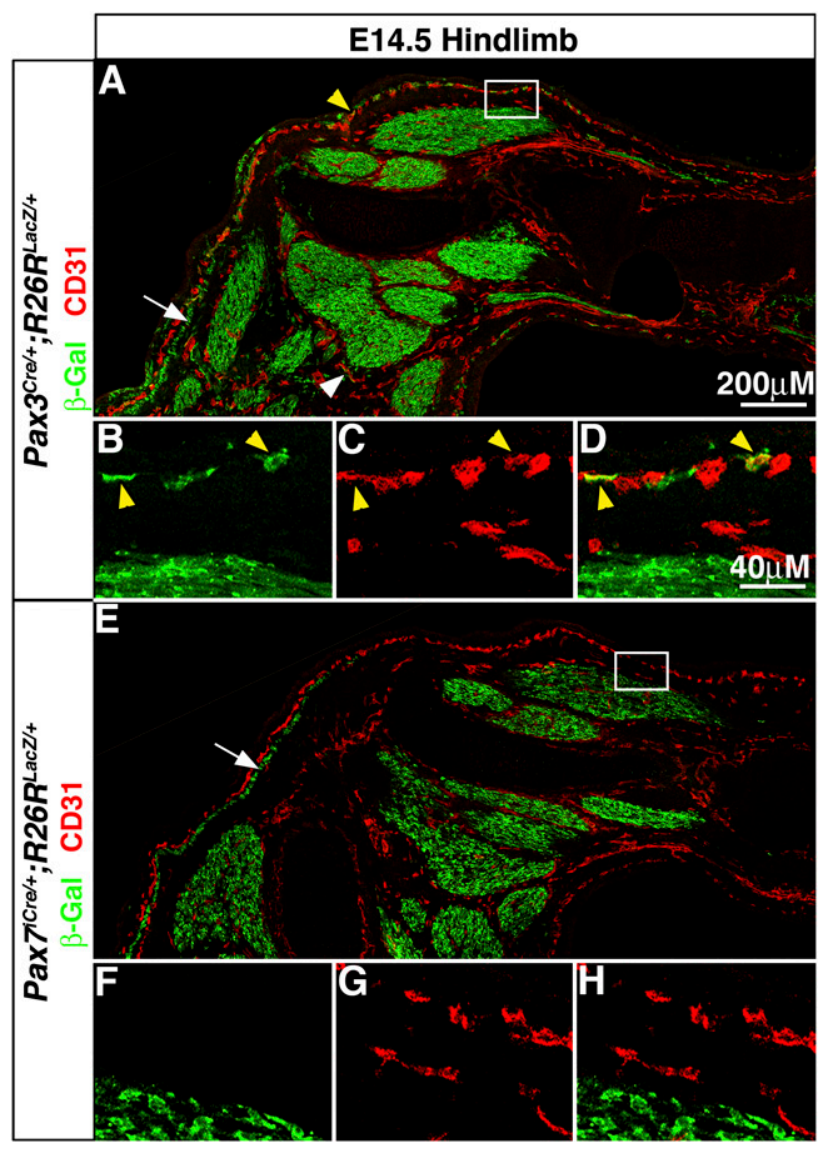

Figure 4. $\mathrm{Pax}^{+}$, but not $\mathrm{Pax} 7^{+}$, somitic cells give rise to limb endothelial cells. $(A-D) \mathrm{CD}^{+} 1^{+}$endothelial cells superficial (yellow arrowheads) and adjacent (white arrowhead) to muscle are $\beta$-gal ${ }^{+}$in E14.5 $\mathrm{Pax}^{\mathrm{Cre} /+}{ } ; \mathrm{R}_{26 \mathrm{R}^{\mathrm{LacZ} /+}}$ hindlimbs. $(\mathrm{E}-\mathrm{H}) \mathrm{CD} 31^{+}$ endothelial cells are not $\beta-\mathrm{gal}^{+}$in $\mathrm{E} 14.5 \mathrm{Pax}^{\mathrm{iCre} /+} ; R_{2} 6 R^{\mathrm{LacZ} /+}$ hindlimbs. Arrows point to subcutaneous trunci muscle near superficial endothelial cells. that $\operatorname{Pax} 7^{+}$somitic cells never differentiate into endothelial cells. This suggests that $\operatorname{Pax} 7^{+}$somitic cells may be restricted, and potentially committed, to a myogenic fate in the limb.

\section{Wnt/ $\beta$-catenin signaling is active in myogenic precursors and myoblasts}

Wnt/ $\beta$-catenin signaling is an important regulator of muscle development and is likely to be critical for embryonic and fetal limb myogenesis. To first determine whether canonical $\beta$-catenin signaling is active within myogenic cells, we examined BAT-gal mice, in which seven TCF/LEF-binding sites drive nuclear LacZ expression when bound by transcriptionally active TCF/LEFs (Maretto et al. 2003). At E12.5 $\mathrm{Pax}^{+} \beta-\mathrm{gal}^{+}$and $\mathrm{MyoD}^{+} \beta$ $\mathrm{gal}^{+}$cells are found in the limb and somites (Supplemental Fig. 4; see also Borello et al. 2006), indicating that Wnt/ $\beta$-catenin signaling is active in myogenic progenitors and myoblasts. Because not all $\mathrm{Pax}^{+}$and $\mathrm{MyoD}^{+}$cells were $\beta$-gal ${ }^{+}$and also BAT-gal mice are inefficient in reporting all cells with active Wnt/ $\beta$-catenin signaling (Barolo 2006), it is unclear whether all or just some myogenic progenitors and myoblasts are active for Wnt $/ \beta$-catenin signaling.

$\beta$-catenin is required in Pax3-derived somitic cells for dermomyotome and myotome formation, but not subsequently in Pax7-derived cells for embryonic axial myogenesis

As Pax3 is initially expressed in the somites and Wnt $/ \beta$ catenin signaling is active there, we first tested whether $\beta$-catenin is required cell-autonomously within the Pax3 lineage for somite development. We generated $\mathrm{Pax}^{\mathrm{Cre} /+}$; $\beta$-catenin ${ }^{\Delta / f 12-6} ; R 26 R^{Y F P /+}$ mice in which both alleles of $\beta$-catenin have been inactivated, via excision of exons 2-6 (Brault et al. 2001), in all $\mathrm{Pax}^{+}$cells and their progeny (the $\Delta$ allele is constitutively inactivated, while the f12-6 allele is inactivated in response to Cre). These mice also contained the Cre-responsive $R 26 R^{Y F P /+}$ reporter (Srinivas et al. 2001) and allowed us to visualize cells, via expression of YFP, in which Cre has been expressed and $\beta$-catenin inactivated. $\mathrm{Pax}_{3}{ }^{\mathrm{Cre} /+} ; \beta$-catenin ${ }^{f 12-6 /+} ; \mathrm{R} 26 \mathrm{R}^{\mathrm{YFP} /+}$ mice, in which only one allele of $\beta$-catenin is excised in response to Cre, serve as heterozygous controls and are indistinguishable from wild type. Cre-mediated reporter expression is present and $\beta$-catenin is inactivated in the somites by E9. Sections through E10.5 somites of $\mathrm{Pax}^{\mathrm{Cre} /+} ; \beta$-catenin ${ }^{\Delta / f 12-6}$; $R 26 R^{Y F P /+}$ mice reveal that the somites are disorganized with poorly formed dermomyotomes and fewer $\mathrm{Pax}^{+}$ progenitors (Supplemental Fig. 5A-H). Since Pax3 and Paraxis are required for formation of epithelial somites and proper dermomyotomes (Burgess et al. 1996; Relaix et al. 2004), we analyzed by whole-mount in situ hybridization expression of Pax3 (Supplemental Fig. 5I) and Paraxis (data not shown). Expression of both genes initiates in the psm and early somites (prior to Cre-mediated inactivation $\beta$-catenin), but is not maintained in mature somites (after $\beta$-catenin inactivation) in $\mathrm{Pax}{ }^{\mathrm{Cre} /{ }^{+}} ; \beta$-cat$e{ }^{2} n^{\Delta / f 12-6} ; R 26 R^{Y F P /+}$ mice. In addition, analysis of $M y o D$ and Myf5 (Supplemental Fig. 5K,L) and myosin (data not 
shown) of $\mathrm{Pax}^{\mathrm{Cre} /+} ; \beta$-catenin ${ }^{\Delta / f 12-6} ; \mathrm{R}^{2} 6 \mathrm{R}^{\mathrm{YFP} /+}$ mice show a complete absence of the myotome with no $M y f 5^{+}$or $\mathrm{MyoD}^{+}$myoblasts or myosin ${ }^{+}$myofibers. We did not see a significant increase in cell death or change in proliferation (as assayed by TUNEL and phospho-histone H3) (data not shown) in the somites of these mice. These data demonstrate that $\beta$-catenin is required within Pax3derived cells for maintenance of Pax3 and Paraxis somitic expression, proper dermomyotome formation, and the subsequent differentiation of myoblasts and myofibers within the myotome.

We also tested whether $\beta$-catenin may be required subsequently for formation of embryonic axial muscles. To test this we generated $\mathrm{Pax}^{\mathrm{iCre} /+} ; \beta$-catenin ${ }^{\Delta / f 12-}$ ${ }^{6}$;R26R ${ }^{Y F P /+}$ mice in which the later expression of $\operatorname{Pax} 7$ drives Cre recombination and widespread inactivation of $\beta$-catenin at E10.5 in the somites. Surprisingly, at E14.5 (at the end of embryonic myogenesis) axial myogenesis appears unperturbed, with a normal pattern of $\mathrm{MyoD}^{+}$ myoblasts (Supplemental Fig. 5M-T) and myosin ${ }^{+}$myofibers (data not shown). Because these myoblasts and myofibers are $\mathrm{YFP}^{+}$, these myogenic cells are Pax7derived and have Cre-mediated inactivation of $\beta$-catenin. The presence of myoblasts and myofibers despite their cell-autonomous inactivation of $\beta$-catenin demonstrates that $\beta$-catenin, although required for dermomyotome and myotome formation, is not required subsequently for embryonic axial myogenesis.

$\beta$-catenin is required in the somite for delamination of limb myogenic progenitors, but not required for embryonic limb myoblasts and myofibers

The disorganization of the dermomyotome in the $\mathrm{Pax} 3^{\mathrm{Cre} /{ }^{+}}$; $\beta$-catenin ${ }^{\Delta / f 12-6 /+} ; R 26 R^{Y F P /+}$ mice suggests that $\beta$-catenin may be required for formation of the ventrolateral dermomyotome and delamination of limb myogenic progenitors. Indeed in E12.5-E14.5 $\mathrm{Pax}^{\mathrm{Cre} / \mathrm{H}} ; \beta$-catenin ${ }^{\Delta / f 12-6} ; \mathrm{R} 26 \mathrm{R}^{\mathrm{YFP} /+}$ mice inactivation of $\beta$-catenin in Pax3-derived cells results in the complete absence of $\mathrm{Pax}^{+}$myogenic progenitors, MyoD $^{+}$myoblasts, or myosin ${ }^{+}$myofibers in the limb (Fig. 5A-H; Supplemental Fig. 6A-P). The lack of any myogenic cells in the limb suggests that Pax3-derived myogenic progenitors did not delaminate from the dermomyotome ventrolateral lip. This delamination process requires the ligand Hgf, expressed in the limb, to signal to its receptor Met, expressed in ventrolateral somitic cells (Dietrich et al. 1999). In the absence of either Hgf or Met, somitic cells fail to delaminate from the ventrolateral dermomyotome and no limb myogenesis occurs (Bladt et al. 1995; Maina et al. 1996). In $\mathrm{Pax3}^{\mathrm{Cre} /+}$; $\beta$-catenin ${ }^{\Delta / f 12-6} ; R 26 R^{Y F P /+}$ mice expression of Met initiates in the most newly formed somites (prior to complete inactivation of $\beta$-catenin) (arrow in Supplemental Fig. 5J), but fails to be maintained in more mature somites and limb myogenic progenitors (after complete inactivation of $\beta$-catenin). This loss of Met expression is likely to result from the loss of $\mathrm{Pax} 3$ in the somites, as it has been previously shown that Met expression is dependent on activation by Pax3 (Epstein et al. 1996). Therefore, $\beta$-catenin is required in the somites to maintain Pax3 expression and $\mathrm{Met}^{+}$ventrolateral dermomyotomal cells that delaminate and migrate into the limb.

Analysis of the BAT-gal reporter mice suggested canonical $\beta$-catenin signaling is active within myogenic cells in the limb. However, the requirement for $\beta$-catenin early in the somites precluded analysis of later roles for $\beta$-catenin in limb myogenesis using $\mathrm{Pax}^{\mathrm{Cre} /+} ; \beta$-catenin ${ }^{\Delta / f 12-6}$; $R 26 R^{Y F P /+}$ mice. Therefore we analyzed $\mathrm{MCr}^{\mathrm{Tg} / \mathrm{H}} ; \beta$ catenin $^{\Delta / f 12-6} ; R 26 R^{Y F P /+}$ mice. MCre mice have a transgene containing a Pax3 enhancer element and proximal promoter expressed only in the ventrolateral lip of the dermomyotome, the body wall, and limb myogenic cells (Brown et al. 2005) and resulting in Cre-mediated recombination in newly delaminated myogenic cells and their progeny (data not shown). In $\mathrm{MCr}^{\mathrm{Tg} /+} ; \beta$-catenin ${ }^{f l 2-6 /+}$; $R 26 R^{Y F P /+}$ mice, in which one allele of $\beta$-catenin is inactivated, $\mathrm{YFP}^{+} \mathrm{MyoD}^{+}$myoblasts (as well as $\mathrm{YFP}^{+} \mathrm{Pax}^{+}$ muscle progenitors and $\mathrm{YFP}^{+}$myofibers) (data not shown) are present (Fig. 5I-L). The efficiency of labeling limb myogenic cells in these mice is considerably lower and more variable than $\mathrm{Pax}_{3}{ }^{\mathrm{Cre} /+}{ }_{;}$R26 ${ }^{\mathrm{YFP} /+}$ mice perhaps because not all elements necessary for Pax3 expression in the hypaxial somitic cells are present in the transgene (Schienda et al. 2006). Nevertheless, in $\mathrm{MCre}^{\mathrm{Tg} /+}$; $\beta$-catenin ${ }^{\Delta / f 12-6} ; R 26 R^{Y F P /+}$ mice, in which both $\beta$-catenin alleles are inactivated, $\mathrm{YFP}^{+} \mathrm{MyoD}^{+}$myoblasts (as well as $\mathrm{YFP}^{+} \mathrm{Pax}^{+}$muscle progenitors and $\mathrm{YFP}^{+}$myofibers) (data not shown) are present (Fig. 5M-P). This indicates that once in the limb $\beta$-catenin is not required within Pax3derived cells for specification of embryonic myoblasts and differentiation of myofibers. Whether the total number of myoblasts and myofibers differs from wild-type levels is difficult to evaluate because of the inefficiency of the $M C r e$ driver.

\section{$\beta$-catenin is not necessary for Pax3-derived limb endothelial cells, nor is it sufficient to drive Pax3 ${ }^{+}$ somitic cells to a myogenic fate}

Our lineage analysis revealed that $\mathrm{Pax}^{+}$somitic cells give rise to limb myogenic and endothelial cells. Potentially, $\beta$-catenin is required in $\mathrm{Pax} 3^{+}$somitic cells for generation of both limb myogenic progenitors and endothelial progenitors. However, in $\mathrm{Pax}^{\mathrm{Cre} /+} ; \beta$-catenin ${ }^{\Delta / f 12-6}$; $R 26 R^{Y F P /+}$ mice $\mathrm{YFP}^{+} \mathrm{CD} 31^{+}$endothelial cells are present in the limb (Fig. 6A-H). This indicates that, unlike myogenic progenitors, Pax3-derived endothelial progenitors do not cell-autonomously require $\beta$-catenin when residing within the somites or subsequently when in the limb for delamination, migration, or differentiation into endothelium. Furthermore, because Met is absent in the $\mathrm{Pax}^{\mathrm{Cre} /{ }} ; \beta$-catenin ${ }^{\Delta / f 12-6} ; \mathrm{R}^{2} 6 \mathrm{R}^{\mathrm{YFP} /+}$ mice, this also indicates that, unlike myogenic progenitors, limb endothelial progenitors do not require $\mathrm{Met}$ for delamination.

Because $\beta$-catenin is required for generation of $\operatorname{limb}$ myogenic but not endothelial cells from the somite, we hypothesized that $\beta$-catenin signaling may act in $\mathrm{Pax}^{+}$ somitic cells as a molecular switch between myogenic and endothelial cell fates. To test this we conducted 


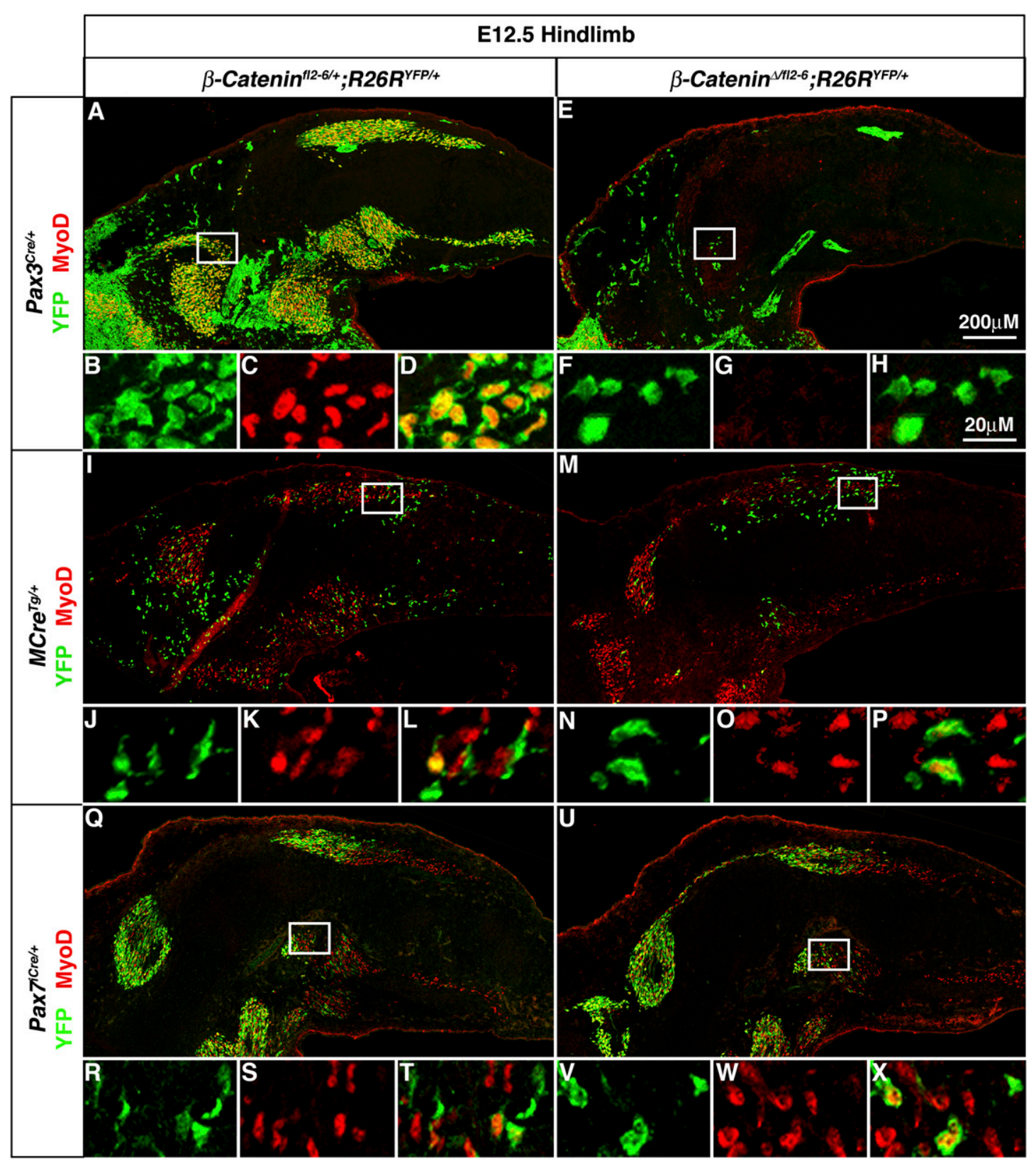

Figure 5. $\quad \beta$-Catenin is required early in Pax3-derived somitic cells for generation of limb myogenic cells, but is not required in Pax3derived migrating progenitors for specification of embryonic myoblasts. Loss of $\beta$-catenin in Pax7-derived cells does not affect myoblast specification. During embryonic myogenesis at E12.5 mutant $P a \times 3{ }^{C r e /+} ; \beta$-catenin ${ }^{\Delta / f 12-6}{ }_{;} R 26 R^{Y F P /+}$ hindlimbs $(E-H)$ contain many fewer $\mathrm{YFP}^{+}$cells in the limb and none give rise to $\mathrm{MyoD}^{+}$myoblasts as compared with heterozygous control Pax ${ }^{\mathrm{Cre} /+}{ }_{;} \beta-\mathrm{catenin}^{\text {fl2-6/+}}{ }^{6}$ $R 26 R^{Y F P /+}$ hindlimbs in which many $\mathrm{YFP}^{+}$cells are present that give rise to $\mathrm{YFP}^{+}$MyoD ${ }^{+}$myoblasts $(A-D)$. In E12.5 mutant $M C r e^{T g /+}$; $\beta$-catenin ${ }^{\Delta / f 12-6} ; R 26 R^{Y F P /+}$ hindlimbs $(M-P)$ in which $\beta$-catenin is inactivated in Pax3-derived cells after delamination from the somite, $\mathrm{YFP}^{+} \mathrm{MyoD}^{+}$myoblasts are present similar to the heterozygous control MCre ${ }^{\text {Tg/+ }} ; \beta$-catenin ${ }^{f 12-6 /+} ;{ }^{2} 26 R^{Y F P /+}$ hindlimbs $(I-L)$. In E12.5 mutant $\mathrm{Pax} 7^{\mathrm{iCre} /{ }^{+}} ; \beta$-catenin ${ }^{\Delta / f 12--6} ; R 26 R^{\mathrm{YFP} /+}$ hindlimbs $(U-X) \mathrm{YFP}^{+} \mathrm{MyoD}^{+}$myoblasts are present in similar numbers as found in heterozygous $\operatorname{Pax}^{\text {iCre/+ }} ; \beta$-catenin ${ }^{f 12-6 /+}{ }_{;} R_{2} 6 R^{\text {YFP/+ }}$ hindlimbs $(Q-T)$.

a gain-of-function experiment in which $\beta$-catenin is conditionally, constitutively activated via a $\beta$-catenin ${ }^{f l 3 /+}$ allele (Harada et al. 1999). In the $\beta$-catenin ${ }^{f l 3 /+}$ allele, the presence of Cre causes deletion of exon 3 and the formation of a stabilized, constitutively activated form of $\beta$-catenin. $\mathrm{Pax}^{\mathrm{Cre} / \mathrm{H}} ; \beta$-catenin ${ }^{f l 3 /+} ; \mathrm{R}^{2} 6 \mathrm{R}^{\mathrm{YFP} /+}$ mice die at E11.5 (prior to the presence of Pax3-derived CD $31^{+}$ cells in the limb at E12.5), and so we analyzed $M C r e^{T g /+}$; $\beta$-catenin ${ }^{f 13 /+}, R 26 R^{Y F P /+}$ mice. If $\beta$-catenin indeed mediates between a myogenic versus an endothelial fate, we anticipated that activation of $\beta$-catenin would drive all somitic progenitors in the limb to a myogenic fate at the expense of an endothelial fate. In contrast, in both E14.5 MCre ${ }^{T g /+} \beta$ - catenin $^{+/+} ; R_{2} 6 R^{Y F P /+}$ and $\mathrm{MCre}^{\mathrm{Tg} /+}$; 

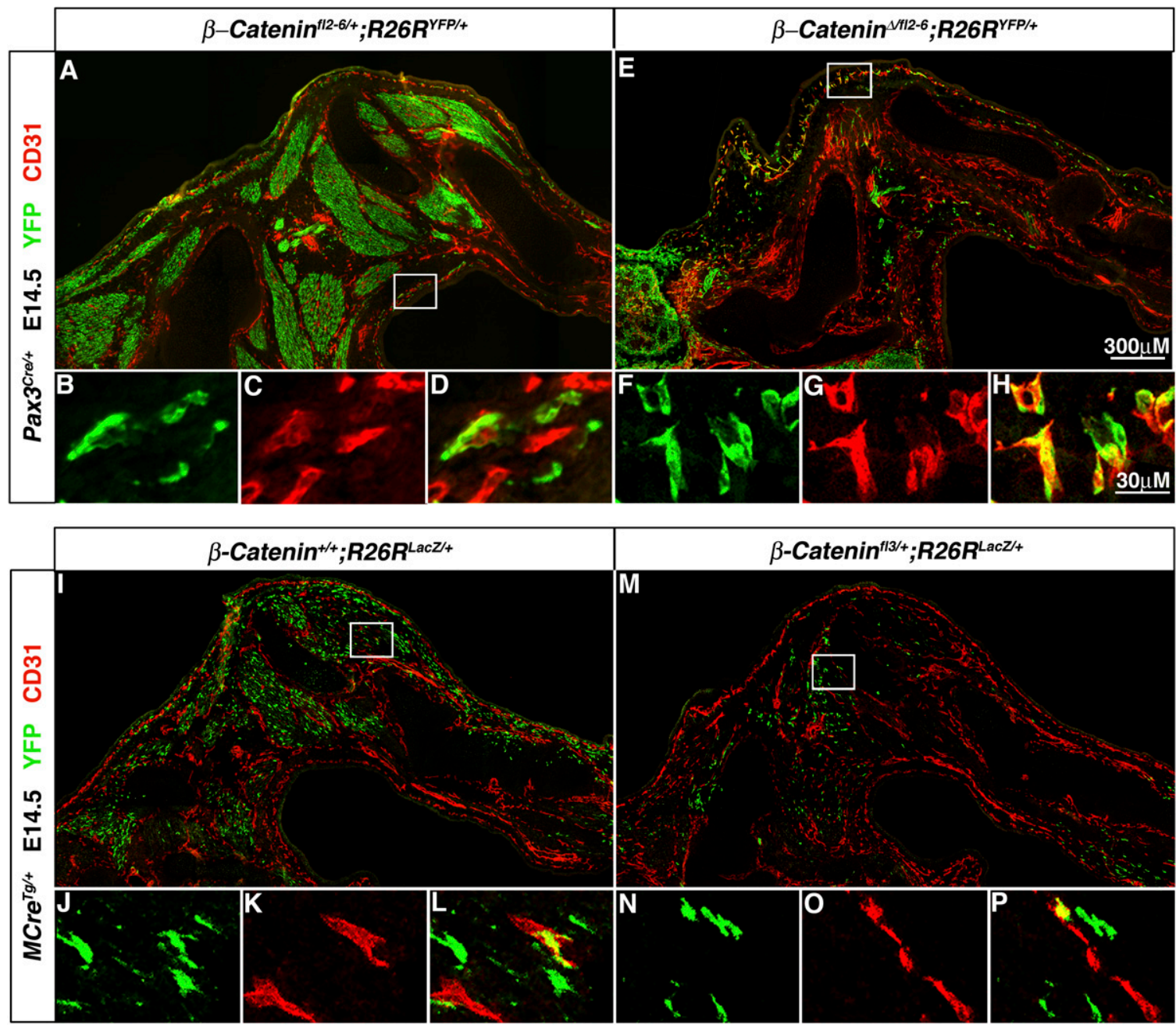

Figure 6. $\beta$-Catenin is not necessary for Pax3-derived limb endothelial cells, nor is it sufficient to drive Pax $3^{+}$somitic cells to a myogenic fate. $(A-D)$ In E14.5 Pax ${ }^{\mathrm{Cre} /+} ; \beta$-catenin ${ }^{f 12-6 /+} ; R 26 R^{\mathrm{YFP} /+}$ hindlimbs $\mathrm{YFP}^{+} \mathrm{CD} 31^{+}$endothelial cells are present. $(E-H)$ In $\mathrm{Pax}^{\mathrm{Cre} /+} ; \beta$-catenin ${ }^{\Delta / f 16} ; R 26 R^{\mathrm{YFP} /+}$ hindlimbs many fewer $\mathrm{YFP}^{+}$cells are present in the limb but these still give rise to $\mathrm{YFP}^{+} \mathrm{CD} 1^{+}$ endothelial cells. $(I-L)$ In E14.5 $\mathrm{MCr}^{\mathrm{Tg} /+} ; \beta$-catenin ${ }^{+/+} ; R 26 R^{\mathrm{LacZ} /+}$ hindlimbs Pax3-derived cells expressing Cre after delamination from the somite give rise to $\mathrm{YFP}^{+} \mathrm{CD} 31^{+}$endothelial cells. $(M-P) \operatorname{In} M C r e^{T g /+} ; \beta$-catenin ${ }^{f 13 /+} ; R 26 R^{L a c Z /+}$ hindlimbs Pax3-derived cells still give rise $\mathrm{YFP}^{+} \mathrm{CD} 31^{+}$.

$\beta$-catenin ${ }^{f l 3 /+} ; R 26 R^{Y F P /+}$ mice we found $\mathrm{YFP}^{+} \mathrm{CD} 31^{+}$endothelial cells (Fig. 6I-P). The presence of MCre-derived endothelial cells even in the presence of constitutively active $\beta$-catenin demonstrates that $\beta$-catenin is not sufficient to drive somitic cells in the limb to a myogenic fate.

\section{$\beta$-catenin is critical for fetal myogenesis in the limb}

Although $\beta$-catenin is not required for embryonic myogenesis once somitic progenitors have entered the limb, $\beta$-catenin may be critical subsequently for fetal myogenesis. To test this, we analyzed $\operatorname{Pax}^{i \mathrm{Cre} /+} ; \beta$-catenin ${ }^{\Delta / f 12-6}$; $R 26 R^{\mathrm{YFP} /+}$ and $\mathrm{Pax} 7^{\mathrm{iCre} /+} ; \beta$-catenin ${ }^{f l 3 /+} ; R 26 R^{\mathrm{YFP} /+}$ mice at P0 (both genotypes die at birth) in which $\beta$-catenin has been either inactivated or constitutively activated in Pax7-derived cells. In $\mathrm{Pax}^{\mathrm{iCre} /+} ; \beta$-catenin ${ }^{\Delta / f 12-6} ; \mathrm{R}^{2} 6 \mathrm{R}^{\mathrm{YFP} /+}$ and $\mathrm{Pax}^{\mathrm{iCre} /+} ; \beta$-catenin ${ }^{f l 3 /+}{ }_{;} 26 \mathrm{R}^{\mathrm{YFP/+}}$ limbs all myofibers are $\mathrm{YFP}^{+}$(data not shown), indicating that Pax7-derived cells contributed to fetal myofibers, despite the inactivation or activation of $\beta$-catenin (Supplemental Fig. 2E-I). In $\mathrm{Pax}{ }^{\mathrm{iCre} /+}{ }_{;} \beta$-catenin ${ }^{\Delta / f 12-6} ; R 26 R^{Y F P /+}$ mice the overall pattern of muscles in the limb is unaffected (Supplemental Fig. 7A). However, individual muscles contain significantly fewer myofibers and in most muscles significantly fewer of the myofibers are slow (Fig. 7A; Supplemental Fig. 7D, 8, 9). In contrast, in $\mathrm{Pax}^{\mathrm{iCre} /{ }^{+}}$; $\beta$-catenin ${ }^{f l 3 /+} ; R 26 R^{Y F P /+}$ mice the pattern of muscles was highly perturbed (Fig. 7C; Supplemental Fig. 7C) with many of the muscle boundaries obscured and myofibers misoriented. There are also fewer myofibers but almost all myofibers are slow, although the irregular fiber orientations make this difficult to quantify (Fig. 7C; Supplemental Fig. 7F). In the $\mathrm{Pax}^{\mathrm{iCre} /+} ; \beta$-catenin ${ }^{\Delta / f 12-6}$; $R 26 R^{Y F P /+}$ and $\mathrm{Pax}^{\mathrm{iCre/+}} ; \beta$-catenin ${ }^{f l 3 /+}{ }_{;} \mathrm{R}_{26 R^{\mathrm{YFP} /+}}$ mice defects in muscle pattern, myofiber number, and/or 


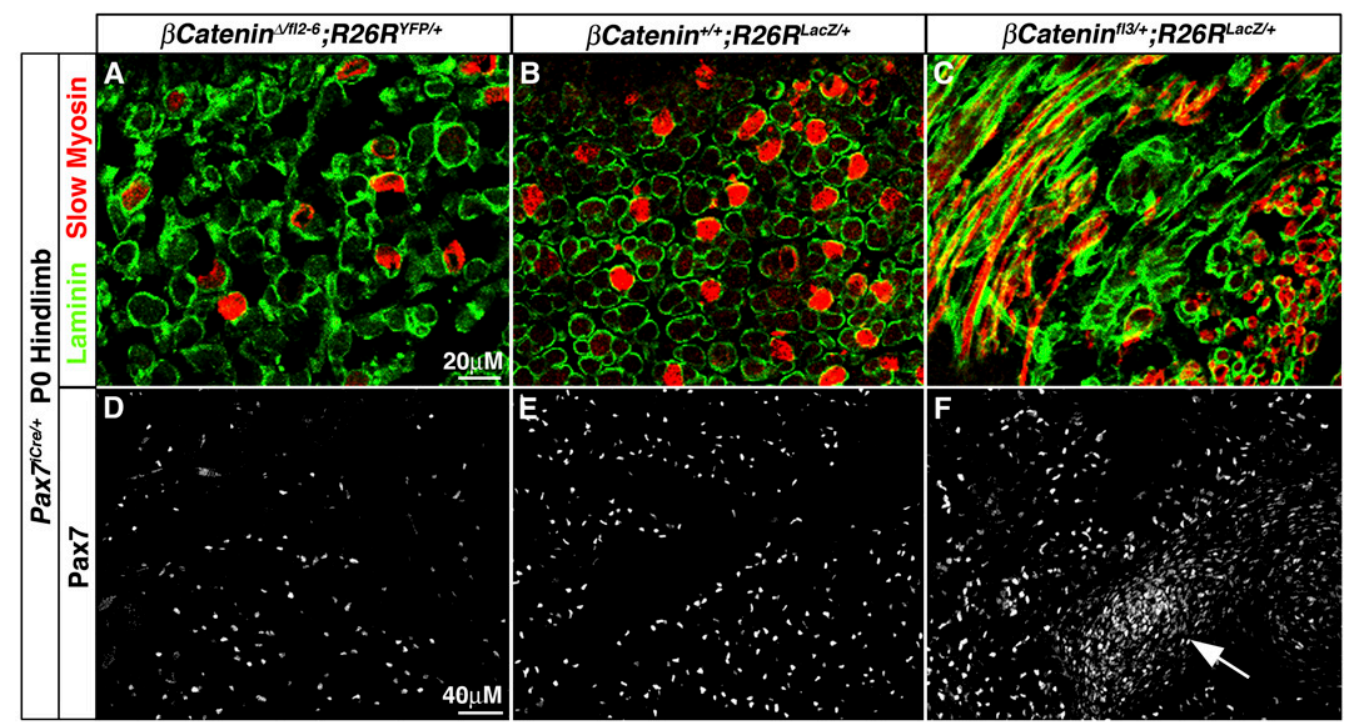

G

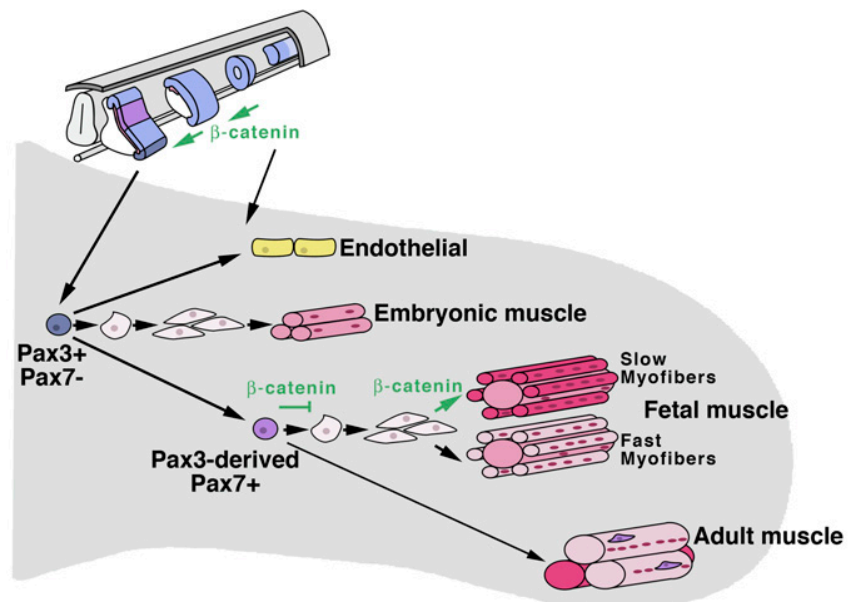

Figure 7. $\beta$-Catenin regulates progenitor number and myofiber number and type during fetal myogenesis in the limb. In P0 Pax $7^{i C r e /+}$; $\beta$-catenin ${ }^{\Delta / f 16} ; R 26 R^{Y F P /+}$ hindlimbs inactivation of $\beta$-catenin in Pax7-derived fetal muscle leads to fewer overall laminin ${ }^{+}$myofibers with a lower proportion of slow myosin ${ }^{+}$myofibers $(A$ vs. $B)$ but relatively the same number of $\operatorname{Pax} 7^{+}$progenitors $(D$ vs. $E)$ as compared

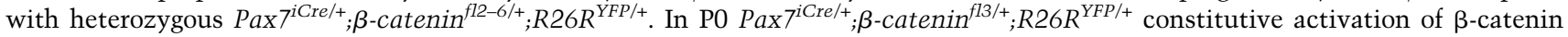
leads to a disorganized pattern of myofibers, fewer overall laminin ${ }^{+}$myofibers with a higher proportion of slow myosin ${ }^{+}$myofibers $(C$ vs. $B$ ), and more Pax $7^{+}$progenitors ( $F$ vs. $E$ ) as compared with $\mathrm{Pax}{ }^{i C r e /+} ; \beta$-catenin ${ }^{f 12-6 /+} ; R 26 R^{Y F P /+}$. (Arrow in $F$ ) Dense concentrations of Pax $7^{+}$progenitors are frequently found in $\mathrm{Pax}^{i \mathrm{Cre} /+} ; \beta$-catenin ${ }^{f l 3 /+} ; R 26 R^{Y F P /+}$ limbs. $(G)$ Model of embryonic and fetal limb myogenesis.

type arose during fetal myogenesis. Muscle pattern is normal in E14.5 $\mathrm{Pax}^{\mathrm{iCre} /+} ; \beta$-catenin ${ }^{f l 3 /+} ; R_{2} 6 R^{\mathrm{YFP} /+}$ mice (data not shown), and a normal pattern of myoblasts (Fig. $5 \mathrm{U}-\mathrm{X}$ ) and myofibers (Supplemental Fig. $6 \mathrm{U}-\mathrm{X}$ ) is present at E12.5-E14.5 in Pax $7^{\text {iCre } /+} ; \beta$-catenin ${ }^{\Delta / f 12-6} ; R 26 R^{Y F P /+}$ mice. It is likely that embryonic muscle is not affected at E12 because Cre-mediated deletion of $\beta$-catenin is just beginning and at E14.5 multinucleate myofibers contain myonuclei derived from $\operatorname{Pax} 7^{+}$precursors in which $\beta$-catenin has been deleted as well as $\mathrm{Pax}^{+} \mathrm{Pax}^{-}$precursors in which $\beta$-catenin is still expressed. Overall, our data show that during fetal myogenesis $\beta$-catenin affects myofiber number and positively regulates the number of slow fibers.

Examination of $\mathrm{Pax}^{\mathrm{iCre} /+} ; \beta$-catenin ${ }^{\Delta / f 12-6} ; R 26 R^{Y F P /+}$ and $\mathrm{Pax}{ }^{\mathrm{iCre} /+} ; \beta$-catenin ${ }^{f 13 /+} ; R 26 R^{Y F P /+} \mathrm{P} 0$ mice also demonstrates that $\beta$-catenin positively regulates the number of $\operatorname{Pax} 7^{+}$myogenic progenitors during fetal myogenesis. Significantly more $\mathrm{Pax} 7^{+}$cells are present in $\mathrm{Pax} 7^{\mathrm{iCre} /{ }^{+}} ; \beta$ catenin $^{f 13 /+}{ }_{;} R_{2} 6 R^{Y F P /+}$ versus $\mathrm{Pax}^{\mathrm{iCre} /+}{ }_{;} \beta$ - catenin $^{+/+}$; $R 26 R^{Y F P /+}$ mice, while the number of $\operatorname{Pax} 7^{+}$cells is not detectably changed in $\mathrm{Pax}^{\text {iCre/+}} ; \beta$-catenin ${ }^{\Delta / f 12-6} ; R 26 R^{Y F P /+}$ mice (Fig. 7D-F; Supplemental Figs. 7G-I, 10). Interestingly, in the $\mathrm{Pax}^{i \mathrm{Cre} /+} ; \beta$-catenin ${ }^{f l 3 /+} ; R_{2} 26 \mathrm{R}^{\mathrm{YFP} /+}$ mice there were regions of dense concentrations of $\mathrm{Pax}^{+}$ cells (arrows in Fig. 7F; Supplemental Fig. 7I). An analysis of $\mathrm{Pax}^{+}$cell proliferation $\left(\mathrm{PHH}^{+} \mathrm{Pax} 7^{+}\right.$cells/ $\mathrm{Pax}^{+}$cells) was inconclusive, as we found high variability both within and between individuals of all genotypes. The dense concentrations of $\operatorname{Pax} 7^{+}$cells in Pax ${ }^{\text {iCre/+}} ; \beta$-catenin ${ }^{f 13 /+}{ }_{;} R 26 R^{Y F P /+}$ mice did not have high levels of $\mathrm{PHH}^{+}$cells (data not shown). Also, an analysis of apoptosis (via TUNEL) did not reveal 
significant levels of cell death in any of the three genotypes (data not shown). Overall, our data show that $\beta$-catenin cell-autonomously positively regulates the number of $\mathrm{Pax}^{+}$muscle progenitors during fetal myogenesis. In particular, activated $\beta$-catenin is sufficient to increase the number of progenitors, but $\beta$-catenin itself is not required for maintenance of $\mathrm{Pax} 7^{+}$progenitors.

\section{Discussion}

Pax $^{+}$somitic cells give rise to muscle and endothelium, while Pax $7^{+}$somitic cells are committed to myogenesis

Pax3 and Pax7 are important regulators of myogenesis and mark myogenic progenitors. To determine the relationship between the $\operatorname{Pax} 3$ and Pax7 lineages in the limb and test whether $\mathrm{Pax}^{+}$and $\mathrm{Pax} 7^{+}$cells are committed myogenic progenitors we genetically labeled and ablated $\mathrm{Pax}^{+}$and $\mathrm{Pax}^{+}$cells. Our lineage analysis reveals that $\mathrm{Pax}^{+}$somitic cells in the limb contribute to both muscle and endothelial cell lineages. Transplantation studies had established that somitic cells contribute to both limb muscle and endothelial cells (Pardanaud et al. 1996; He et al. 2003; Huang et al. 2003), and chick lineage studies showed that even single somitic cells are bipotential, contributing to muscle and endothelium (Kardon et al. 2002). Here we show that $\mathrm{Pax}^{+}$somitic cells are bipotential in the limb. Thus, even though $P a x 3$ is a member of the genetic cascade committing cells to myogenesis (Maroto et al. 1997; Tajbakhsh et al. 1997; Bajard et al. 2006; Buchberger et al. 2007), in vivo expression of Pax3 in somitic cells is not sufficient to commit these cells to a myogenic fate.

We also found that $\mathrm{Pax}^{+}$cells are a subset of $\mathrm{Pax}^{+}$ somitic cells and only give rise to myogenic, and not endothelial cells. Our ablation studies demonstrate that the Pax3 lineage is required for the emergence of $\mathrm{Pax}^{+}$ cells, even though Pax3 function is not required for the specification of $\mathrm{Pax}^{+}$cells $\left(\mathrm{Pax} 7^{+}\right.$cells are present in axial muscles of $\mathrm{Pax}^{-/-}$mice) (Kassar-Duchossoy et al. 2005). Subsequently, Pax7 somitic derivatives appear to be restricted, and therefore potentially committed, to the muscle lineage. Whether the expression of Pax7 itself commits $\mathrm{Pax}^{+}$cells to myogenesis or simply marks committed cells is unclear. Pax7 regulates Myf5 expression (McKinnell et al. 2008), and myogenesis (with the exception of the primary myotome) requires either Pax3 or Pax7 expression (Relaix et al. 2005). Recently Pax7 has been shown to be more stable than Pax3, which is subject to monoubiquitination and proteasomal degradation (Boutet et al. 2007). An attractive hypothesis is that Pax3 expression initially establishes intermediate, bipotential precursors (see Lang et al. 2005; Boutet et al. 2007). Given the right extrinsic cues, some of these $\mathrm{Pax}^{+}$cells differentiate into muscle (or endothelium). However, $\mathrm{Pax}^{+}$cells that do not differentiate subsequently express the more stable Pax7, committing these cells to a myogenic fate via Pax7 activation of Myf5 expression.
$\mathrm{Pax}^{+} \mathrm{Pax}^{-}$somitic cells are required for embryonic myogenesis, while Pax3-derived Pax $7^{+}$somitic cells are required for fetal myogenesis in the limb

Recent studies have argued that $\mathrm{Pax} 3^{+} / \mathrm{Pax} 7^{+}$cells are common muscle progenitors for embryonic and fetal myoblasts and muscle (Kassar-Duchossoy et al. 2005; Relaix et al. 2005). We used genetic lineage and ablation studies to fully assess the contribution of $\mathrm{Pax}^{+}$and Pax $7^{+}$cells to limb muscle and find that these two lineages contribute differentially to embryonic and fetal limb myogenesis.

Our lineage analysis of $\mathrm{Pax}^{+}$and $\mathrm{Pax} 7^{+}$cells found that all limb embryonic muscle is derived from Pax $3^{+}$cells. Moreover, the loss of all embryonic myofibers when $\mathrm{Pax}^{+}$cells are ablated demonstrates that these cells are required for limb embryonic myogenesis. Ablation of $\mathrm{Pax}^{+}$cells also leads to loss of all axial muscles. Thus, although Pax3 function is only required for limb muscle development (all limb muscle is lost in $\mathrm{Pax}^{-/-}$mice) (Relaix et al. 2004 and references therein), $\mathrm{Pax} 3^{+}$cells are required for both limb and trunk muscle development. We also find that $\operatorname{Pax} 7^{+}$cells contribute little to and are not required for embryonic muscle in the limb. This shows that, although $\operatorname{Pax} 7^{+}$cells later contribute to all myofibers during fetal myogenesis, $\operatorname{Pax} 3^{+} \mathrm{Pax} 7^{-}$cells set up the embryonic muscle pattern. Similar to the founder model of Drosophila muscle development (Maqbool and Jagla 2007), the $\operatorname{Pax} 3^{+} \mathrm{Pax} 7^{-}$cells act as founder cells, establishing an initial muscle template on which $\mathrm{Pax} 7^{+}$ cells subsequently fuse.

$\mathrm{Pax}^{+}$cells give rise to and are required for fetal myogenic cells. Pax $7^{+}$cells are Pax3-derived and do not necessarily express Pax3, as Pax3 is generally no longer expressed after E13.5. The loss of fetal myofibers when the Pax7 lineage is ablated highlights the important role of $\mathrm{Pax}^{+}$cells for fetal myogenesis. This role is consistent with expression and microarray studies showing that $\mathrm{Pax} 7$ is expressed in fetal myoblasts (Horst et al. 2006; Biressi et al. 2007b). However, this role has not been revealed by analysis of $\mathrm{Pax} 7^{-1-}$ mice, in which fetal myogenesis appears normal although adult satellite cells are not maintained and adult myogenesis and regeneration are severely compromised (Seale et al. 2000; Oustanina et al. 2004; Kuang et al. 2006; Relaix et al. 2006). During fetal myogenesis either Pax7's function is not essential or is compensated by other proteins. Nevertheless, clearly, $\mathrm{Pax} 7^{+}$cells are required for fetal growth and fiber-type maturation.

\section{$\beta$-catenin is required for dermomytome and myotome formation, but not subsequently for embryonic axial myogenesis}

Multiple studies have demonstrated that Wnt/ $\beta$-catenin signaling is important for axial and limb myogenesis. Nevertheless, still unanswered is whether $\beta$-catenin signaling is required cell-autonomously in vivo for embryonic and fetal myogenesis. To address these questions, we first demonstrated that $\mathrm{Wnt} / \beta$-catenin signaling is active in myogenic progenitors and myoblasts. We then 
tested genetically whether $\beta$-catenin is critical for myogenesis by conditional inactivation or constitutive activation of $\beta$-catenin within the $\operatorname{Pax} 3$ and $\operatorname{Pax} 7$ lineages.

During axial muscle development, $\beta$-catenin is required within the Pax3 lineage for dermomyotome formation. Inactivation of $\beta$-catenin in the most newly formed somites in $\mathrm{Pax}^{\mathrm{Cre} /+} ; \beta$-catenin ${ }^{\Delta / f 12-6}$ mice resulted in disorganized somites with poorly formed dermomyotomes. The poor formation of epithelial dermomyotomes suggests that $\beta$-catenin's cell adhesion function may be critical. Alternatively, $\beta$-catenin's function in Wnt signaling may be critical. Similar dermomyotome defects have been found in $W n t 1^{-/-} ; W n t 3 a^{-/-}$mice (Ikeya and Takada 1998) as well as embryos in which Wnt/ $\beta$-catenin/Lef1 signaling is blocked (Schmidt et al. 2004; Linker et al. 2005). The dermomyotomal defects in $\mathrm{Pax}^{\mathrm{Cre} / \mathrm{H}} ; \beta$-catenin ${ }^{\Delta / f 12-6}$ mice may be mediated by Pax3 and Paraxis. Previous studies showed that these genes are critical for proper formation of epithelial somites and dermomyotomes (Burgess et al. 1996; Relaix et al. 2004), and Pax 3 and Paraxis expression is not maintained in somites of $\mathrm{Pax}_{3}{ }^{\mathrm{Cre} /}{ }_{;} ;$-catenin ${ }^{\Delta / f 12-6}$ mice. These data, combined with expression studies (e.g., Tajbakhsh et al. 1998; Borello et al. 1999a, 2006), suggest that Wnts, produced in the neural tube and ectoderm, activate $\beta$-catenin/Lef1 signaling within newly formed somites, which regulates Paraxis and Pax3 expression and is critical for proper dermomyotome formation.

Inactivation of $\beta$-catenin in the most newly formed somites also ablated the myotome, $M y o D$ and Myf5 expression, and subsequently all axial muscle. The loss of $M y o D$ and Myf5 is consistent with Myf5 and MyoD down-regulation in the myotome of $W n t 1^{-/-} ; W n t 3 a^{-/-}$ mice and in psm explants in which Wnt/ $\beta$-catenin signaling has been blocked (Borello et al. 1999b; Linker et al. 2003; Brunelli et al. 2007). However, the complete loss of $M y o D$ is unexpected given recent explant data suggesting that $M y o D$ expression is predominantly regulated by a Wnt/PKC pathway (Chen et al. 2005; Brunelli et al. 2007). Multiple mechanisms may explain why $\beta$-catenin is required for both myotomal Myf5 and MyoD. Two Tcf/Lef-binding sites in the early epaxial enhancer of Myf5 are critical for myotomal Myf5 expression (Borello et al. 2006). However, the incomplete loss of Myf5 after deletion of these binding sites, as compared with the complete loss of Myf5 in the $\mathrm{Pax}^{\mathrm{Cre} /+} ; \beta$-catenin ${ }^{\Delta / f l 2-6}$ mice, suggests that $\beta$-catenin may also be regulating $M y f 5$ via other mechanisms. $M y o D$ is not regulated by direct $\beta$-catenin/Tcf/Lef transcriptional activation as no Tcf/Lef-binding sites have been found in the core enhancer controlling $M y o D$ expression (Kucharczuk et al. 1999). Paraxis may be an important mediator between $\beta$-catenin signaling and Myf5 and MyoD expression; Paraxis is down-regulated in $\mathrm{Pax}^{\mathrm{Cre} /{ }_{;}} \beta \beta_{\text {-catenin }}{ }^{\mathrm{L} / \mathrm{fl}-6}$ mice and in Paraxis $^{-1-}$ mice Myf5 and MyoD are down-regulated (Burgess et al. 1996; Wilson-Rawls et al. 1999). Nevertheless, the incomplete loss of Myf5 and MyoD in Paraxis $^{-/-}$ mice suggests that loss of Paraxis cannot explain the complete loss of Myf5 and MyoD in $\mathrm{Pax}^{\mathrm{Cre} /+} ; \beta$-catenin ${ }^{\Delta / f 12-6}$ mice. Finally, Pax 3 may also mediate the loss of Myf5 and
MyoD expression; Pax3 expression is not maintained in $\mathrm{Pax}^{\mathrm{Cre} /+} ; \beta$-catenin ${ }^{\Delta / f 12-6}$ mice, and Pax3 has been shown to bind and activate $M y f 5$ and $M y o D$ enhancers (Bajard et al. 2006; Hu et al. 2008). Therefore, $\beta$-catenin is likely playing multiple roles in myotome formation, and it is loss of all these functions that results in the complete loss of myotomal Myf5 and MyoD. The consequence of both the loss of the dermomyotome, which gives rise to later axial muscle progenitors (Gros et al. 2005; Relaix et al. 2005), and the myotome, which serves as a scaffold for these progenitors, is the subsequent loss of all axial muscles in $\mathrm{Pax}^{\mathrm{Cre} /+}$; $\beta$ - catenin $^{\Delta / f 12-6}$ mice.

After dermomyotome and myotome formation, surprisingly, $\beta$-catenin is not required within myogenic cells for embryonic axial myogenesis. In $\mathrm{Pax}^{\mathrm{iCre} /+} ; \beta$-catenin ${ }^{\Delta / f 12-6}$ mice, $\beta$-catenin is deleted in $\operatorname{Pax} 7^{+}$progenitors and their derivatives in stage $\mathrm{X}$ somites, in which the dermomyotome and myotome have already formed. Despite the loss of $\beta$-catenin in the Pax7 lineage, embryonic axial myogenesis is normal, indicating that $\beta$-catenin is not required at this later stage of myogenesis. Thus, although many experiments demonstrate that $\mathrm{Wnt} / \beta$-catenin signaling is important for axial myogenesis (for review, see Cossu and Borello 1999; Borycki and Emerson 2000), we find that $\beta$-catenin is essential for dermomyotome and myotome development but not critical for embryonic axial myogenesis. Previous explant and in vivo chick experiments all manipulate $\mathrm{Wnt} / \beta$-catenin signaling in the psm and early somites, thus affecting dermomyotome, myotome, and subsequent axial myogenesis. Our results emphasize the difference between the developmental requirements for the myotome versus those for later embryonic axial myogenesis. Such differences are also evident in the Myf5 enhancer where the early epaxial enhancer only drives expression in the myotome (Teboul et al. 2002); in $\mathrm{Pax}^{-/-} ; \mathrm{Pax}^{-/-}$mutants where the primary myotome is formed, but subsequent axial myogenesis is ablated (Relaix et al. 2005); and in $\mathrm{Myf5}^{-/-}$; $\mathrm{Mrf4}^{-/-}$mice where the myotome fails to form, but subsequent myogenesis is relatively normal (KassarDuchossoy et al. 2005).

\section{Pax3-derived limb endothelial cells do not require $\beta$-catenin}

We found that Pax3-derived limb endothelial cells migrate and differentiate independent of $\beta$-catenin. In $\mathrm{Pax}^{\mathrm{Cre} /+} ; \beta$-catenin ${ }^{\Delta / f 12-6}$ mice, despite the absence of a dermomyotome and Met expression, endothelial progenitors migrate from the somites into the limb. Similarly, Geetha-Loganathan et al. (2006) have found in chick endothelial cells do not, while myogenic cells do, require Wnt6 for their emigration from the somites into the limb. Pax3-derived endothelial progenitors may be intrinsically different from myogenic progenitors within the somite and thus not require the dermomyotomal lip and Met expression for their migration. However, the finding of individual somitic cells that give rise to endothelial and myogenic cells argues against this interpretation (Kardon et al. 2002). Alternatively, Pax $3^{+}$cells migrating (perhaps 
earlier) from the somites independent of the dermomyotomal lip and Met enter a limb environment that promotes an endothelial fate. Subsequently, once in the limb Pax3-derived endothelial cells do not require $\beta$-catenin for their differentiation, nor does $\beta$-catenin promote a myogenic versus an endothelial cell fate.

Once in the limb, myogenic cells do not require $\beta$-catenin for embryonic myogenesis but require $\beta$-catenin for fetal myogenesis

$\beta$-catenin plays several cell-autonomous roles during limb myogenesis. First within the somite $\beta$-catenin is required for formation of the dermomyotome and maintenance of $P a \times 3$ and Met expression, which are prerequisites for delamination of limb myogenic cells (Bladt et al. 1995; Maina et al. 1996; Dietrich et al. 1999; Relaix et al. 2003, 2004). Subsequently, once in the limb embryonic and fetal myogenic cells have different requirements for $\beta$-catenin.

Limb myogenic cells do not require $\beta$-catenin for specification of embryonic myoblasts and differentiation of myofibers. We found, via analysis of BAT-gal embryos, that canonical $\beta$-catenin signaling is active in limb myogenic progenitors and myoblasts. Yet, deletion of $\beta$-catenin cell-autonomously within limb myogenic cells had no obvious effect on embryonic myoblast specification and myofiber differentiation. This indicates that, despite the presence of active $\beta$-catenin signaling within some myogenic cells, during normal limb development $\beta$-catenin is not critical for embryonic myogenesis. It is possible that $\beta$-catenin regulates the overall number of limb embryonic myoblasts and myofibers, but this possibility could only be evaluated with a more robust Cre driver (e.g., a tamoxifen-inducible Pax3 $^{\text {CreERT2 }}$ ).

During fetal myogenesis, $\beta$-catenin is critical for determining the number of $\operatorname{Pax}^{+}$progenitors and myofibers. $\beta$-Catenin positively regulates the overall number of $\operatorname{Pax} 7^{+}$progenitors, but did not detectably or consistently regulate their rate of proliferation or cell death. Recent in vitro studies on adult satellite cells show that nuclear, dephosphorylated $\beta$-catenin is present in activated satellite cells and Wnts and $\beta$-catenin promote self-renewal of Pax $7^{+}$satellite cells (Otto et al. 2008; Perez-Ruiz et al. 2008; but see Brack et al. 2008). Because $\beta$-catenin either does not consistently affect (our finding) or slows (PerezRuiz et al. 2008) $\mathrm{Pax} 7^{+}$cell proliferation and does not alter apoptosis (our finding; Perez-Ruiz et al. 2008), this suggests that $\beta$-catenin may expand the number of $\operatorname{Pax} 7^{+}$ fetal myoblasts or satellite cells by preventing their differentiation. The frequent appearance of dense clusters of Pax $7^{+}$cells that are not highly proliferative in $\mathrm{Pax} 7^{\mathrm{iCre} /+}$; $\beta$-catenin ${ }^{f l 3 /+}$ mice supports this notion. We also found that the overall myofiber number decreased when either $\beta$-catenin was deleted or constitutively activated in Pax7derived cells. Myofiber number is determined by several factors: progenitor number, rate of proliferation, and rate of differentiation and fusion. Fewer myofibers may be present in $\mathrm{Pax}^{\mathrm{iCre} /+} ; \beta$-catenin ${ }^{\Delta / f 12-6}$ mice because progenitors prematurely differentiate (as found in vitro by
Gavard et al. 2004; Perez-Ruiz et al. 2008), ultimately resulting in the formation of fewer myofibers. In $\mathrm{Pax} 7^{\mathrm{iCre} /+}$; $\beta$-catenif ${ }^{f l 3 /+}$ mice, reduction in myofibers is likely due to a block in progenitor differentiation and fusion, as constitutive activation of $\beta$-catenin has been shown in vitro to block myogenic differentiation and fusion /Goichberg et al. 2001; Gavard et al. 2004; Perez-Ruiz et al. 2008). Mechanistically how $\beta$-catenin is functioning is unclear. Currently, there are multiple proposals for how $\beta$-catenin regulates adult myogenesis that may be applicable to fetal myogenesis. $\beta$-Catenin can function via canonical Wnt/ $\beta$-catenin signaling (Brack et al. 2008; Otto et al. 2008; Perez-Ruiz et al. 2008), but can also regulate myogenesis by direct modification of MRF transcriptional activity (Pan et al. 2005; Kim et al. 2008) and by modification of adherens junctions and cell adhesion (Goichberg et al. 2001; Gavard et al. 2004; Nastasi et al. 2004; Kramerova et al. 2006).

Finally, we also found that $\beta$-catenin positively modulates the number of slow myofibers during fetal myogenesis. How $\beta$-catenin regulates the expression of slow myosin is potentially complex. $\beta$-Catenin may be negatively regulating the maturation of embryonic myofibers so that more retain slow myosin, positively regulating fetal myofibers so that more acquire slow myosin, and/or increasing the relative proportion of slow $\operatorname{myosin}^{+} \mathrm{em}$ bryonic myofibers versus slow myosin ${ }^{-}$fetal myofibers.

\section{Model of embryonic and fetal myogenesis in the limb}

Vertebrate myogenesis occurs in three successive phases: embryonic, fetal, and adult. The embryonic, fetal, and adult myoblasts responsible for these phases of myogenesis are distinct. However, it has been unclear whether these classes of myoblasts arise from common or different progenitors. From our lineage and ablation studies a model of the developmental origin of embryonic and fetal myogenic cells in the limb emerges (Fig. 7G). $\mathrm{Pax} 3^{+} \mathrm{Pax} 7^{-}$somitic cells initially entering the limb are bipotential progenitors and contribute to limb muscle and endothelium. These cells give rise to and are required for embryonic myogenesis. $\mathrm{Pax} 3^{+}$cells also give rise to $\mathrm{Pax} 7^{+}$cells. These Pax3-derived, $\mathrm{Pax} 7^{+}$cells give rise to and are required for fetal myogenesis. Subsequently, some of these Pax3-derived, $\mathrm{Pax}^{+}$cells also give rise to adult satellite cells, critical for adult myogenesis (Gros et al. 2005; Kassar-Duchossoy et al. 2005; Relaix et al. 2005; Schienda et al. 2006). Thus, in the limb embryonic and fetal myoblasts arise from developmentally distinct, although related, progenitors. Future in vitro and expression studies using recently identified genes expressed in embryonic versus fetal myoblasts (Biressi et al. 2007b) will further test whether $\operatorname{Pax} 3^{+} \operatorname{Pax} 7^{-}$cells are embryonic myogenic progenitors, while Pax3-derived $\mathrm{Pax} 7^{+}$cells are fetal myogenic progenitors.

During development, functional contractile, post-mitiotic myofibers must differentiate to allow for movement, while proliferating progenitors must be maintained for growth. Therefore, in the same environment some myogenic progenitors must differentiate, while others must 
maintain their proliferative status. It has been hypothesized that embryonic, fetal and adult progenitors and/or myoblasts are intrinsically different so that these cells will respond differently to similar environmental signals (Biressi et al. 2007a,b). For instance, in vitro TGF $\beta$ inhibits differentiation of fetal but not embryonic myoblasts (Cusella-De Angelis et al. 1994). Here we show in vivo that the different progenitor populations have different cell-autonomous requirements for $\beta$-catenin (Fig. 7G). In the somite $\beta$-catenin is required in Pax3derived cells for dermomyotome and myotome formation and delamination of myogenic, but not endothelial, progenitors. Once in the limb $\mathrm{Pax} 3^{+} \mathrm{Pax} 7^{-}$cells and their progeny do not require $\beta$-catenin for embryonic myoblast specification and myofiber differentiation. During fetal myogenesis $\beta$-catenin is critical within the Pax7 lineage for determining progenitor number and myofiber number and type. If $\beta$-catenin is functioning via canonical Wnt $/ \beta$-catenin signaling this suggests that the fetal Pax 7 lineage is sensitive to Wnts. In contrast, the embryonic Pax $3^{+} \mathrm{Pax} 7^{-}$lineage appears to be insensitive to Wnt signals. Thus differential sensitivity to Wnt signaling may be a mechanism to allow embryonic progenitors to differentiate, but maintain a fetal progenitor population.

\section{Materials and methods}

Mice

All lines of mice were generated previously and reported. Cre drivers included Pax3 $3^{\mathrm{Cre}}$ (Engleka et al. 2005), Pax $7^{\text {iCre }}$ (Keller et al. 2004), and MCre (Brown et al. 2005); reporters included $R 26 R^{\text {LacZ }}$ (Soriano 1999), $R 26 R^{Y F P}$ (Srinivas et al. 2001), and BATgal (Maretto et al. 2003); and conditional alleles included $\beta$-catenin loss-of-function $\beta$-catenin ${ }^{\Delta / f 12-6}$ (Brault et al. 2001), constitutive gain-of-function $\beta$-catenin ${ }^{f l 3 /+}$ (Harada et al. 1999), and cell ablation $R 26 R^{D T A}$ (Wu et al. 2006).

$\beta$-gal staining, immunofluorescence, microscopy, and in situ hybridization

Whole-mount $\beta$-gal staining protocol is online at http://genetics. med.harvard.edu/ cepko/protocol/xgalplap-stain.htm. For section immunofluorescence, $12-\mu \mathrm{m}$ cryosections were washed in PBS and then, if needed (see Supplemental Table 1), subjected to antigen retrieval, consisting of heating slides in citrate buffer (1.8 mM citric acid, $8.2 \mathrm{mM}$ sodium citrate in $\mathrm{H}_{2} \mathrm{O}$ ) in a 2100 PickCell Retriever. Slides were incubated $1 \mathrm{~h}$ in $5 \%$ goat serum in PBS, overnight at $4^{\circ} \mathrm{C}$ in $1^{\circ}$ antibody, washed in PBS, for $2 \mathrm{~h}$ at room temperature in $2^{\circ}$ antibody, washed in PBS, and stained 5 min Hoechst. Primary antibodies are listed in Supplemental Table 1 and secondary antibodies consisted of Alexa 488 or 594 goat anti-mouse IgG1 (Invitrogen) or Cy2 or Cy3 goat anti-rabbit, anti-rat, or anti-chick (Jackson ImmunoResearch). All sections were imaged on a Zeiss TCS SP5 confocal microscope. Each image is a composite of maximum projections derived from stacks of optical sections. Whole-mount in situ hybridization protocol is online at http://genetics.med.harvard.edu/ cepko/ protocol/ctlab/ish.ct.htm.

\section{Cell counts and statistics}

For counts of laminin ${ }^{+}$myofibers, $\mathrm{MHCslow}^{+}$myofibers, and $\operatorname{Pax} 7^{+}$cells the three sections in the center of each muscle or limb were identified. Total and slow myofibers were counted by hand and $\mathrm{Pax} 7^{+}$and $\mathrm{PH} 3^{+} \mathrm{Pax} 7^{+}$cells were counted using ImageJ software. Counts for three sections of three individuals for each genotype were analyzed using a repeated-measures ANOVA with JMP7 software.

\section{Acknowledgments}

We thank Cori Compton for initial help with this project, and A. Letsou, L.C. Murtaugh, F. Relaix, and members of the Kardon laborartory for helpful comments. NIH R01 HD053728 to G.K. funded this work.

\section{References}

Anakwe, K., Robson, L., Hadley, J., Buxton, P., Church, V., Allen, S., Hartmann, C., Harfe, B., Nohno, T., Brown, A.M., et al. 2003. Wnt signalling regulates myogenic differentiation in the developing avian wing. Development 130: 3503-3514.

Bajard, L., Relaix, F., Lagha, M., Rocancourt, D., Daubas, P., and Buckingham, M.E. 2006. A novel genetic hierarchy functions during hypaxial myogenesis: Pax3 directly activates Myf5 in muscle progenitor cells in the limb. Genes \& Dev. 20: 24502464.

Barolo, S. 2006. Transgenic Wnt/TCF pathway reporters: All you need is Lef? Oncogene 25: 7505-7511.

Biressi, S., Molinaro, M., and Cossu, G. 2007a. Cellular heterogeneity during vertebrate skeletal muscle development. Dev. Biol. 308: 281-293.

Biressi, S., Tagliafico, E., Lamorte, G., Monteverde, S., Tenedini, E., Roncaglia, E., Ferrari, S., Cusella-De Angelis, M.G., Tajbakhsh, S., and Cossu, G. 2007b. Intrinsic phenotypic diversity of embryonic and fetal myoblasts is revealed by genome-wide gene expression analysis on purified cells. Dev. Biol. 304: 633-651.

Bladt, F., Riethmacher, D., Isenmann, S., Aguzzi, A., and Birchmeier, C. 1995. Essential role for the c-met receptor in the migration of myogenic precursor cells into the limb bud. Nature 376: 768-771.

Borello, U., Buffa, V., Sonnino, C., Melchionna, R., Vivarelli, E., and Cossu, G. 1999a. Differential expression of the Wnt putative receptors Frizzled during mouse somitogenesis. Mech. Dev. 89: 173-177.

Borello, U., Coletta, M., Tajbakhsh, S., Leyns, L., De Robertis, E.M., Buckingham, M., and Cossu, G. 1999b. Transplacental delivery of the Wnt antagonist Frzbl inhibits development of caudal paraxial mesoderm and skeletal myogenesis in mouse embryos. Development 126: 4247-4255.

Borello, U., Berarducci, B., Murphy, P., Bajard, L., Buffa, V., Piccolo, S., Buckingham, M., and Cossu, G. 2006. The Wnt/ $\beta$-catenin pathway regulates Gli-mediated Myf5 expression during somitogenesis. Development 133: 3723-3732.

Borycki, A.G. and Emerson Jr., C.P. 2000. Multiple tissue interactions and signal transduction pathways control somite myogenesis. Curr. Top. Dev. Biol. 48: 165-224.

Boutet, S.C., Disatnik, M.H., Chan, L.S., Iori, K., and Rando, T.A. 2007. Regulation of Pax3 by proteasomal degradation of monoubiquitinated protein in skeletal muscle progenitors. Cell 130: 349-362.

Brack, A.S., Conboy, I.M., Conboy, M.J., Shen, J., and Rando, T.A. 2008. A temporal switch from notch to Wnt signaling in muscle stem cells is necessary for normal adult myogenesis. Cell Stem Cell 2: 50-59.

Brault, V., Moore, R., Kutsch, S., Ishibashi, M., Rowitch, D.H., McMahon, A.P., Sommer, L., Boussadia, O., and Kemler, R. 2001 . Inactivation of the $\beta$-catenin gene by Wnt1-Cre-mediated 
deletion results in dramatic brain malformation and failure of craniofacial development. Development 128: 1253-1264.

Brown, C.B., Engleka, K.A., Wenning, J., Min Lu, M., and Epstein, J.A. 2005. Identification of a hypaxial somite enhancer element regulating Pax3 expression in migrating myoblasts and characterization of hypaxial muscle Cre transgenic mice. Genesis 41: 202-209.

Brunelli, S., Relaix, F., Baesso, S., Buckingham, M., and Cossu, G. 2007. $\beta$ Catenin-independent activation of MyoD in presomitic mesoderm requires PKC and depends on Pax3 transcriptional activity. Dev. Biol. 304: 604-614.

Bryson-Richardson, R.J. and Currie, P.D. 2008. The genetics of vertebrate myogenesis. Nat. Rev. Genet. 9: 632-646.

Buchberger, A., Freitag, D., and Arnold, H.H. 2007. A homeopaired domain-binding motif directs Myf5 expression in progenitor cells of limb muscle. Development 134: 11711180.

Buckingham, M. 2007. Skeletal muscle progenitor cells and the role of Pax genes. C. R. Biol. 330: 530-533.

Burgess, R., Rawls, A., Brown, D., Bradley, A., and Olson, E.N. 1996. Requirement of the paraxis gene for somite formation and musculoskeletal patterning. Nature 384: 570-573.

Chen, A.E., Ginty, D.D., and Fan, C.M. 2005. Protein kinase A signalling via CREB controls myogenesis induced by Wnt proteins. Nature 433: 317-322.

Christ, B. and Brand-Saberi, B. 2002. Limb muscle development. Int. J. Dev. Biol. 46: 905-914.

Clevers, H. 2006. Wnt $/ \beta$-catenin signaling in development and disease. Cell 127: 469-480.

Condon, K., Silberstein, L., Blau, H.M., and Thompson, W.J. 1990. Development of muscle fiber types in the prenatal rat hindlimb. Dev. Biol. 138: 256-274.

Cossu, G. and Borello, U. 1999. Wnt signaling and the activation of myogenesis in mammals. EMBO J. 18: 6867-6872.

Cusella-De Angelis, M.G., Molinari, S., Le Donne, A., Coletta, M., Vivarelli, E., Bouche, M., Molinaro, M., Ferrari, S., and Cossu, G. 1994. Differential response of embryonic and fetal myoblasts to TGF $\beta$ : A possible regulatory mechanism of skeletal muscle histogenesis. Development 120: 925933.

Dietrich, S., Abou-Rebyeh, F., Brohmann, H., Bladt, F., SonnenbergRiethmacher, E., Yamaai, T., Lumsden, A., Brand-Saberi, B., and Birchmeier, C. 1999. The role of SF/HGF and c-Met in the development of skeletal muscle. Development 126: 16211629.

Engleka, K.A., Gitler, A.D., Zhang, M., Zhou, D.D., High, F.A., and Epstein, J.A. 2005. Insertion of Cre into the Pax3 locus creates a new allele of Splotch and identifies unexpected Pax3 derivatives. Dev. Biol. 280: 396-406.

Epstein, J.A., Shapiro, D.N., Cheng, J., Lam, P.Y., and Maas, R.L. 1996. Pax3 modulates expression of the c-Met receptor during limb muscle development. Proc. Natl. Acad. Sci. 93: 4213-4218.

Galli, L.M., Willert, K., Nusse, R., Yablonka-Reuveni, Z., Nohno, T., Denetclaw, W., and Burrus, L.W. 2004. A proliferative role for Wnt-3a in chick somites. Dev. Biol. 269: 489-504.

Gavard, J., Marthiens, V., Monnet, C., Lambert, M., and Mege, R.M. 2004. N-cadherin activation substitutes for the cell contact control in cell cycle arrest and myogenic differentiation: Involvement of $\mathrm{p} 120$ and $\beta$-catenin. J. Biol. Chem. 279: 36795-36802.

Geetha-Loganathan, P., Nimmagadda, S., Prols, F., Patel, K., Scaal, M., Huang, R., and Christ, B. 2005. Ectodermal Wnt6 promotes Myf5-dependent avian limb myogenesis. Dev. Biol. 288: 221-233.
Geetha-Loganathan, P., Nimmagadda, S., Huang, R., Scaal, M., and Christ, B. 2006. Role of Wnt-6 in limb myogenesis. Anat. Embryol. (Berl.) 211: 183-188.

Goichberg, P., Shtutman, M., Ben-Ze'ev, A., and Geiger, B. 2001. Recruitment of $\beta$-catenin to cadherin-mediated intercellular adhesions is involved in myogenic induction. J. Cell Sci. 114: 1309-1319.

Gros, J., Manceau, M., Thome, V., and Marcelle, C. 2005. A common somitic origin for embryonic muscle progenitors and satellite cells. Nature 435: 954-958.

Gunning, P. and Hardeman, E. 1991. Multiple mechanisms regulate muscle fiber diversity. FASEB J. 5: 3064-3070.

Haldar, M., Karan, G., Tvrdik, P., and Capecchi, M.R. 2008. Two cell lineages, myf5 and myf5-independent, participate in mouse skeletal myogenesis. Dev. Cell 14: 437-445.

Harada, N., Tamai, Y., Ishikawa, T., Sauer, B., Takaku, K., Oshima, M., and Taketo, M.M. 1999. Intestinal polyposis in mice with a dominant stable mutation of the $\beta$-catenin gene. EMBO I. 18: 5931-5942.

He, L., Papoutsi, M., Huang, R., Tomarev, S.I., Christ, B., Kurz, H., and Wilting, J. 2003. Three different fates of cells migrating from somites into the limb bud. Anat. Embryol. (Berl.) 207: 29-34.

Horst, D., Ustanina, S., Sergi, C., Mikuz, G., Juergens, H., Braun, T., and Vorobyov, E. 2006. Comparative expression analysis of Pax3 and Pax7 during mouse myogenesis. Int. J. Dev. Biol. 50: 47-54.

Hu, P., Geles, K.G., Paik, J.H., DePinho, R.A., and Tjian, R. 2008. Codependent activators direct myoblast-specific MyoD transcription. Dev. Cell 15: 534-546.

Huang, R., Zhi, Q., and Christ, B. 2003. The relationship between limb muscle and endothelial cells migrating from single somite. Anat. Embryol. (Berl.) 206: 283-289.

Ikeya, M. and Takada, S. 1998. Wnt signaling from the dorsal neural tube is required for the formation of the medial dermomyotome. Development 125: 4969-4976.

Kardon, G., Campbell, J.K., and Tabin, C.J. 2002. Local extrinsic signals determine muscle and endothelial cell fate and patterning in the vertebrate limb. Dev. Cell 3: 533-545.

Kassar-Duchossoy, L., Gayraud-Morel, B., Gomes, D., Rocancourt, D., Buckingham, M., Shinin, V., and Tajbakhsh, S. 2004. Mrf4 determines skeletal muscle identity in Myf5:Myod double-mutant mice. Nature 431: 466-471.

Kassar-Duchossoy, L., Giacone, E., Gayraud-Morel, B., Jory, A., Gomes, D., and Tajbakhsh, S. 2005. Pax3/Pax7 mark a novel population of primitive myogenic cells during development. Genes \& Dev. 19: 1426-1431.

Keller, C., Hansen, M.S., Coffin, C.M., and Capecchi, M.R. 2004. Pax3:Fkhr interferes with embryonic Pax3 and Pax7 function: Implications for alveolar rhabdomyosarcoma cell of origin. Genes \& Dev. 18: 2608-2613.

Kelly, A.M. and Rubinstein, N.A. 1980. Why are fetal muscles slow? Nature 288: 266-269.

Kim, C.H., Neiswender, H., Baik, E.J., Xiong, W.C., and Mei, L. 2008. $\beta$-Catenin interacts with MyoD and regulates its transcription activity. Mol. Cell. Biol. 28: 2941-2951.

Kramerova, I., Kudryashova, E., Wu, B., and Spencer, M.J. 2006. Regulation of the M-cadherin- $\beta$-catenin complex by calpain 3 during terminal stages of myogenic differentiation. Mol. Cell. Biol. 26: 8437-8447.

Kuang, S., Charge, S.B., Seale, P., Huh, M., and Rudnicki, M.A. 2006. Distinct roles for Pax 7 and Pax3 in adult regenerative myogenesis. J. Cell Biol. 172: 103-113.

Kucharczuk, K.L., Love, C.M., Dougherty, N.M., and Goldhamer, D.J. 1999. Fine-scale transgenic mapping of the MyoD core enhancer: MyoD is regulated by distinct but overlapping 
mechanisms in myotomal and non-myotomal muscle lineages. Development 126: 1957-1965.

Lang, D., Lu, M.M., Huang, L., Engleka, K.A., Zhang, M., Chu, E.Y., Lipner, S., Skoultchi, A., Millar, S.E., and Epstein, J.A. 2005. Pax3 functions at a nodal point in melanocyte stem cell differentiation. Nature 433: 884-887.

Linker, C., Lesbros, C., Stark, M.R., and Marcelle, C. 2003. Intrinsic signals regulate the initial steps of myogenesis in vertebrates. Development 130: 4797-4807.

Linker, C., Lesbros, C., Gros, J., Burrus, L.W., Rawls, A., and Marcelle, C. 2005. $\beta$-Catenin-dependent Wnt signalling controls the epithelial organisation of somites through the activation of paraxis. Development 132: 3895-3905.

Maina, F., Casagranda, F., Audero, E., Simeone, A., Comoglio, P.M., Klein, R., and Ponzetto, C. 1996. Uncoupling of Grb2 from the Met receptor in vivo reveals complex roles in muscle development. Cell 87: 531-542.

Maqbool, T. and Jagla, K. 2007. Genetic control of muscle development: Learning from Drosophila. J. Muscle Res. Cell Motil. 28: 397-407.

Maretto, S., Cordenonsi, M., Dupont, S., Braghetta, P., Broccoli, V., Hassan, A.B., Volpin, D., Bressan, G.M., and Piccolo, S. 2003. Mapping Wnt $/ \beta$-catenin signaling during mouse development and in colorectal tumors. Proc. Natl. Acad. Sci. 100: 3299-3304.

Maroto, M., Reshef, R., Munsterberg, A.E., Koester, S., Goulding, M., and Lassar, A.B. 1997. Ectopic Pax-3 activates MyoD and Myf-5 expression in embryonic mesoderm and neural tissue. Cell 89: 139-148.

McKinnell, I.W., Ishibashi, J., Le Grand, F., Punch, V.G., Addicks, G.C., Greenblatt, J.F., Dilworth, F.J., and Rudnicki, M.A. 2008. Pax7 activates myogenic genes by recruitment of a histone methyltransferase complex. Nat. Cell Biol. 10: 77-84.

Miller, K.A., Barrow, J., Collinson, J.M., Davidson, S., Lear, M., Hill, R.E., and Mackenzie, A. 2007. A highly conserved Wntdependent TCF4 binding site within the proximal enhancer of the anti-myogenic Msxl gene supports expression within Pax3-expressing limb bud muscle precursor cells. Dev. Biol. 311: 665-678.

Munsterberg, A.E., Kitajewski, J., Bumcrot, D.A., McMahon, A.P., and Lassar, A.B. 1995. Combinatorial signaling by Sonic hedgehog and Wnt family members induces myogenic bHLH gene expression in the somite. Genes \& Dev. 9: 29112922.

Nastasi, T., Bongiovanni, A., Campos, Y., Mann, L., Toy, J.N., Bostrom, J., Rottier, R., Hahn, C., Conaway, J.W., Harris, A.J., et al. 2004. Ozz-E3, a muscle-specific ubiquitin ligase, regulates $\beta$-catenin degradation during myogenesis. Dev. Cell 6: 269-282

Otto, A., Schmidt, C., and Patel, K. 2006. Pax3 and Pax7 expression and regulation in the avian embryo. Anat. Embryol. (Berl.) 211: 293-310.

Otto, A., Schmidt, C., Luke, G., Allen, S., Valasek, P., Muntoni, F., Lawrence-Watt, D., and Patel, K. 2008. Canonical Wnt signalling induces satellite-cell proliferation during adult skeletal muscle regeneration. J. Cell Sci. 121: 2939-2950.

Oustanina, S., Hause, G., and Braun, T. 2004. Pax7 directs postnatal renewal and propagation of myogenic satellite cells but not their specification. EMBO J. 23: 3430-3439.

Pan, W., Jia, Y., Wang, J., Tao, D., Gan, X., Tsiokas, L., Jing, N., $\mathrm{Wu}, \mathrm{D}$., and Li, L. 2005. $\beta$-Catenin regulates myogenesis by relieving I-mfa-mediated suppression of myogenic regulatory factors in P19 cells. Proc. Natl. Acad. Sci. 102: 17378-17383.

Pardanaud, L., Luton, D., Prigent, M., Bourcheix, L.M., Catala, M., and Dieterlen-Lievre, F. 1996. Two distinct endothelial lineages in ontogeny, one of them related to hemopoiesis. Development 122: 1363-1371.

Perez-Ruiz, A., Ono, Y., Gnocchi, V.F., and Zammit, P.S. 2008. $\beta$-Catenin promotes self-renewal of skeletal-muscle satellite cells. J. Cell Sci. 121: 1373-1382.

Relaix, F., Polimeni, M., Rocancourt, D., Ponzetto, C., Schafer, B.W., and Buckingham, M. 2003. The transcriptional activator PAX3-FKHR rescues the defects of Pax3 mutant mice but induces a myogenic gain-of-function phenotype with ligandindependent activation of Met signaling in vivo. Genes \& Dev. 17: 2950-2965.

Relaix, F., Rocancourt, D., Mansouri, A., and Buckingham, M. 2004. Divergent functions of murine Pax3 and Pax7 in limb muscle development. Genes \& Dev. 18: 1088-1105.

Relaix, F., Rocancourt, D., Mansouri, A., and Buckingham, M. 2005. A Pax3/Pax7-dependent population of skeletal muscle progenitor cells. Nature 435: 948-953.

Relaix, F., Montarras, D., Zaffran, S., Gayraud-Morel, B., Rocancourt, D., Tajbakhsh, S., Mansouri, A., Cumano, A., and Buckingham, M. 2006. Pax3 and Pax7 have distinct and overlapping functions in adult muscle progenitor cells. J. Cell Biol. 172: 91-102.

Schienda, J., Engleka, K.A., Jun, S., Hansen, M.S., Epstein, J.A., Tabin, C.J., Kunkel, L.M., and Kardon, G. 2006. Somitic origin of limb muscle satellite and side population cells. Proc. Natl. Acad. Sci. 103: 945-950.

Schmidt, M., Tanaka, M., and Munsterberg, A. 2000. Expression of $\beta$-catenin in the developing chick myotome is regulated by myogenic signals. Development 127: 4105-4113.

Schmidt, C., Stoeckelhuber, M., McKinnell, I., Putz, R., Christ, B., and Patel, K. 2004. Wnt 6 regulates the epithelialisation process of the segmental plate mesoderm leading to somite formation. Dev. Biol. 271: 198-209.

Schubert, F.R., Tremblay, P., Mansouri, A., Faisst, A.M., Kammandel, B., Lumsden, A., Gruss, P., and Dietrich, S. 2001. Early mesodermal phenotypes in splotch suggest a role for Pax3 in the formation of epithelial somites. Dev. Dyn. 222: 506-521.

Seale, P., Sabourin, L.A., Girgis-Gabardo, A., Mansouri, A., Gruss, P., and Rudnicki, M.A. 2000. Pax7 is required for the specification of myogenic satellite cells. Cell 102: 777-786.

Seale, P., Ishibashi, J., Scime, A., and Rudnicki, M.A. 2004. Pax7 is necessary and sufficient for the myogenic specification of $\mathrm{CD} 45^{+}: \mathrm{Scal}^{+}$stem cells from injured muscle. PLOS Biol. 2: E130. doi: 10.1371/journal.pbio.0020130.

Soriano, P. 1999. Generalized lacZ expression with the ROSA26 Cre reporter strain. Nat. Genet. 21: 70-71.

Srinivas, S., Watanabe, T., Lin, C.S., William, C.M., Tanabe, Y., Jessell, T.M., and Costantini, F. 2001. Cre reporter strains produced by targeted insertion of EYFP and ECFP into the ROSA26 locus. BMC Dev. Biol. 1: 4. doi: 10.1186/1471-213X$1-4$.

Stockdale, F.E. 1992. Myogenic cell lineages. Dev. Biol. 154: 284-298.

Tajbakhsh, S., Rocancourt, D., Cossu, G., and Buckingham, M. 1997. Redefining the genetic hierarchies controlling skeletal myogenesis: Pax-3 and Myf-5 act upstream of MyoD. Cell 89: 127-138.

Tajbakhsh, S., Borello, U., Vivarelli, E., Kelly, R., Papkoff, J., Duprez, D., Buckingham, M., and Cossu, G. 1998. Differential activation of Myf5 and MyoD by different Wnts in explants of mouse paraxial mesoderm and the later activation of myogenesis in the absence of Myf5. Development 125: 4155-4162.

Takata, H., Terada, K., Oka, H., Sunada, Y., Moriguchi, T., and Nohno, T. 2007. Involvement of Wnt4 signaling during myogenic proliferation and differentiation of skeletal muscle. Dev. Dyn. 236: 2800-2807. 
Teboul, L., Hadchouel, J., Daubas, P., Summerbell, D., Buckingham, M., and Rigby, P.W. 2002. The early epaxial enhancer is essential for the initial expression of the skeletal muscle determination gene Myf5 but not for subsequent, multiple phases of somitic myogenesis. Development 129: 4571-4580.

Wigmore, P.M. and Evans, D.J. 2002. Molecular and cellular mechanisms involved in the generation of fiber diversity during myogenesis. Int. Rev. Cytol. 216: 175-232.

Wilson-Rawls, J., Hurt, C.R., Parsons, S.M., and Rawls, A. 1999. Differential regulation of epaxial and hypaxial muscle development by paraxis. Development 126: 5217-5229.

Wu, S., Wu, Y., and Capecchi, M.R. 2006. Motoneurons and oligodendrocytes are sequentially generated from neural stem cells but do not appear to share common lineagerestricted progenitors in vivo. Development 133: 581-590. 


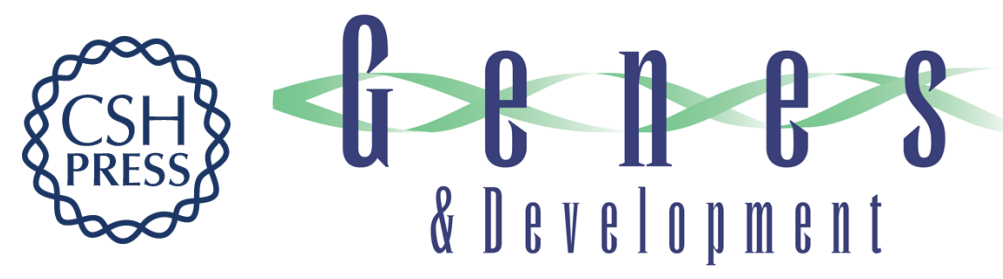

\section{Embryonic and fetal limb myogenic cells are derived from developmentally distinct progenitors and have different requirements for $\beta$-catenin}

David A. Hutcheson, Jia Zhao, Allyson Merrell, et al.

Genes Dev. 2009, 23: originally published online April 3, 2009

Access the most recent version at doi:10.1101/gad.1769009

Supplemental Material

References License

Email Alerting Service
http://genesdev.cshlp.org/content/suppl/2009/04/06/gad.1769009.DC1

This article cites 88 articles, 38 of which can be accessed free at: http://genesdev.cshlp.org/content/23/8/997.full.html\#ref-list-1

Receive free email alerts when new articles cite this article - sign up in the box at the top right corner of the article or click here.

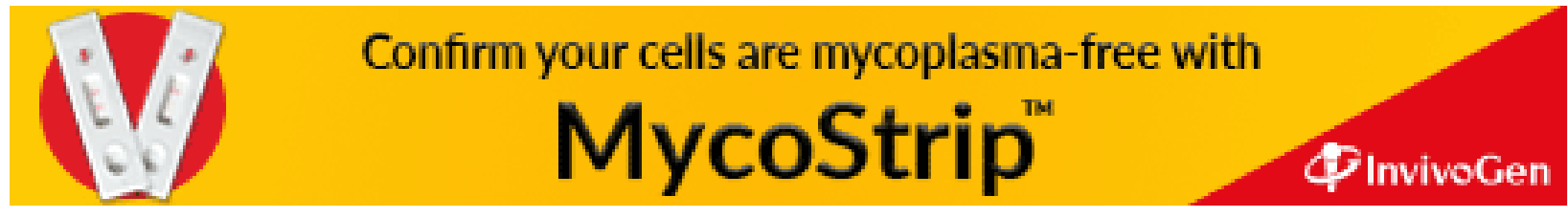

